Atmos. Chem. Phys. Discuss., 11, 10525-10555, 2011

www.atmos-chem-phys-discuss.net/11/10525/2011/

doi:10.5194/acpd-11-10525-2011

(c) Author(s) 2011. CC Attribution 3.0 License.
Atmospheric

Chemistry and Physics Discussions

\title{
Wind speed dependent size-resolved parameterization for the organic enrichment of sea spray
}

B. Gantt ${ }^{1}$, N. Meskhidze ${ }^{1}$, M. C. Facchini ${ }^{2}$, M. Rinaldi ${ }^{2}$, D. Ceburnis ${ }^{3}$, and C. O'Dowd ${ }^{3}$

${ }^{1}$ North Carolina State University, Raleigh, NC, USA

${ }^{2}$ Institute of Atmospheric Sciences and Climate (ISAC), National Research Council (CNR), Bologna, Italy

${ }^{3}$ School of Physics and Centre for Climate and Air Pollution Studies, Ryan Institute, National University of Ireland Galway, University Road, Galway, Ireland

Received: 25 February 2011 - Accepted: 21 March 2011 - Published: 4 April 2011

Correspondence to: N. Meskhidze (nmeskhidze@ncsu.edu)

Published by Copernicus Publications on behalf of the European Geosciences Union.

Wind speed dependent

size-resolved parameterization

B. Gantt et al.

Title Page

Abstract

Introduction

Conclusions

Tables

References

Figures

14

$\triangleleft$

Back

Full Screen / Esc

Printer-friendly Version

Interactive Discussion

105 


\section{Abstract}

For oceans to become a significant source of primary organic aerosol (POA), sea spray must be highly enriched with organics relative to the bulk seawater. We propose that organic enrichment at the air-sea interface, chemical composition of seawater, and the 5 aerosol size are three main parameters controlling the organic mass fraction of sea spray aerosol $\left(\mathrm{OM}_{\mathrm{ss}}\right)$. To test this hypothesis, we developed a new marine POA emission function based on a conceptual relationship between the organic enrichment at the air-sea interface and surface wind speed. The resulting parameterization is explored using aerosol chemical composition and surface wind speed from Atlantic and 10 Pacific coastal stations, and satellite-derived ocean concentrations of chlorophyll-a, dissolved organic carbon, and particulate organic carbon. Of all the parameters examined, a multi-variable logistic regression revealed that the combination of $10 \mathrm{~m}$ wind speed and surface chlorophyll-a concentration ([Chl-a]) are the most consistent predictors of $\mathrm{OM}_{\mathrm{ss}}$. This relationship, combined the published aerosol size dependence of $\mathrm{OM}_{\mathrm{ss}}$, resulted in a new parameterization for the organic carbon fraction of sea spray. Global marine primary organic emission is investigated here by applying this newly-developed relationship to existing sea spray emission functions, satellite-derived [Chl-a], and modeled 10 meter winds. Analysis of model simulations show that global annual submicron marine organic emission associated with sea spray is estimated to

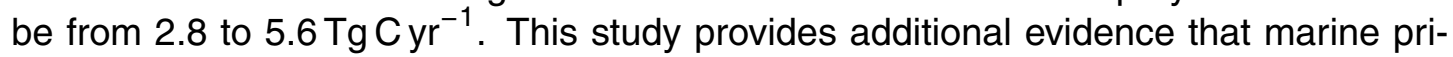
mary organic aerosols are a globally significant source of organics in the atmosphere.

\section{Introduction}

Indirect radiative forcing of anthropogenic aerosols is the major source of uncertainty in climate projections today (IPCC, 2007). A large fraction of this uncertainty may be related to the number concentration and size distribution of marine aerosol that are prescribed or diagnosed in global climate models (GCMs) (Hoose et al., 2009), and

\section{Wind speed dependent size-resolved parameterization}

B. Gantt et al.

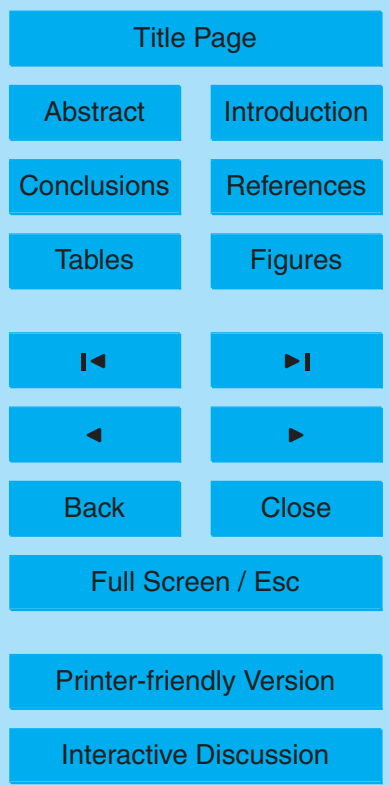


the uncertainties associated with forcings and feedbacks involving marine clouds and precipitation (Bony and Dufresne, 2005; Clement et al., 2009). Marine aerosols are particularly important as they contribute considerably to the global aerosol load and are emitted from a large area of the Earth's surface underlying an atmosphere with low 5 aerosol concentration. The lower bounds (typically from 10 to $40 \mathrm{~cm}^{-3}$ ) of background aerosol concentration often prescribed in GCMs can vary the simulated aerosol indirect effect by over $80 \%$, from $-1.8 \mathrm{~W} \mathrm{~m}^{-2}$ to $-0.2 \mathrm{~W} \mathrm{~m}^{-2}$ (Hoose et al., 2009).

Although sea-salt typically dominates total marine aerosol mass burden and emission rates, organic aerosols of marine origin can contribute a considerable fraction of 10 the submicron aerosol mass concentration near biologically productive waters (O'Dowd et al., 2004). Organic aerosol concentrations of up to $3.8 \mu \mathrm{g} \mathrm{m}^{-3}$ have been observed on the Atlantic coast of Ireland during periods of onshore flow (Ovadnevaite et al., 2011) where on average $\sim 80 \%$ of the carbonaceous material has been directly linked to plankton emissions (Ceburnis et al., 2011). Cloud condensation nuclei (CCN) over 15 the remote oceans typically range from a few tens per $\mathrm{cm}^{3}$ over biologically inactive regions (seasons) to a few hundred per $\mathrm{cm}^{3}$ under biologically active conditions (Andreae, 2007). Since cloud properties are most sensitive to the addition of particles when the background concentration is low (Platnick and Twomey, 1994), ambient measurements, remote sensing, and modeling studies indicate that ocean biology could 20 influence marine cloud microphysical properties (Shaw et al., 1983; Charlson et al., 1987; Middlebrook et al., 1998; O'Dowd et al., 2004; Meskhidze and Nenes, 2006, 2010; Bigg and Leck, 2008; Sorooshian et al., 2009, 2010; Thomas et al., 2010).

Organic aerosols in the marine boundary layer are proposed to have different sources that can be broadly classified as primary, produced from the mechanical process of bubble bursting, and secondary (SOA), derived from precursor biogenic volatile organic compounds (BVOCs) emitted by phytoplankton and macroalgae or by photolysis of chromophoric dissolved organic matter (CDOM) in the water column (Zhou and Mopper, 1997; O'Dowd and de Leeuw, 2007; Sellegri et al., 2008). In addition, SOA can also be derived from the chemical transformation of primary or secondary components

\section{Wind speed dependent size-resolved parameterization}

B. Gantt et al.

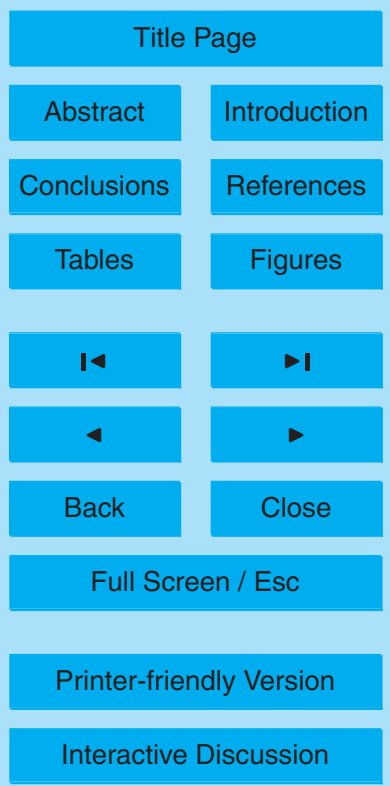

10527 
present in the condensed phase. Such complex transformations could take place at the particle surface or in the aqueous phase, and may also involve a further step through the gas phase in which semivolatile aerosol components can be oxidized to form new condensable products (Rinaldi et al., 2010). Due to the potentially impor5 tant contribution of marine organic aerosol to the CCN budget over the remote ocean, improvement of the fundamental process-level understanding of marine primary and secondary aerosol production mechanisms is needed to develop more reliable parameterizations that can be confidently applied in GCMs. These new parameterizations must capture the total mass of marine organic aerosol emission as well as their cloud 10 nucleating properties (i.e., number concentration and size dependent chemical composition of submicron sea spray). Here, we examine the factors that affect the emission of marine primary organic aerosols (POA).

Laboratory and ambient measurements have revealed that the organic fraction of submicron sea spray aerosols can be enriched (relative to the underlying seawater) by 15 as much as 2 to 3 orders of magnitude (Blanchard, 1964; Gershey, 1983a; Hoffman and Duce, 1974, 1976; Oppo et al., 1999; Keene et al., 2007; Facchini et al., 2008; Russell et al., 2010). The organic enrichment of sea spray is thought to be controlled by the accumulation of insoluble organic matter at the air-sea interface (Hoffman and Duce, 1976; Gershey et al., 1983b). This natural enrichment of the ocean surface layer by organics has been shown to be a function of both meteorological factors, such as surface wind speed, and oceanic parameters including the concentration of dissolved organic carbon ([DOC]), particulate organic carbon ([POC]), chlorophyll-a ([Chl-a]), and type of organic carbon $(\mathrm{OC}$ ) in the air-sea interface and underlying water (Hoffman and Duce, 1976; Gershey, 1983a, b; O'Dowd et al., 2004, 2008; Russell et al., 2010).

25 The air-sea interface can roughly be thought of as being in three regimes where (1) very high organic enrichment leads to visible biogenic surface slicks thicker than $50 \mu \mathrm{m}$, (2) moderate organic enrichment leads to a non-slick microlayer $\sim 50 \mu \mathrm{m}$ thick, and (3) no enrichment is present. Figure 1 shows the conceptual relationship between the organic enrichment of the air-sea interface (given as an OC/Na ratio based on

\section{ACPD}

$11,10525-10555,2011$

\section{Wind speed dependent size-resolved parameterization}

B. Gantt et al.

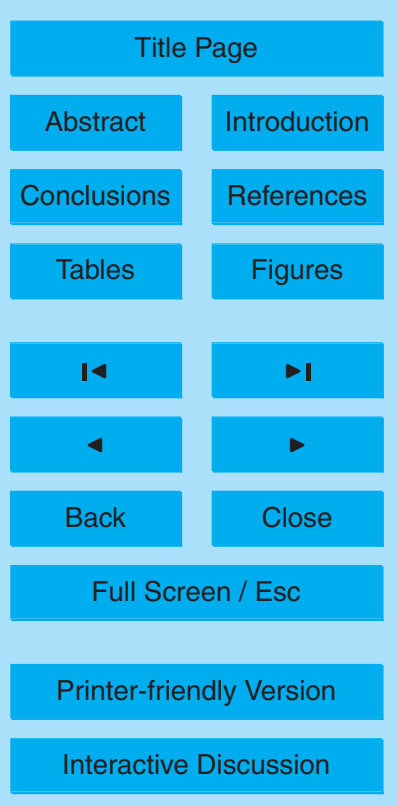


values summarized by Russell et al., 2010) and surface wind speed based on a review of previous works. This figure shows that for given chemical composition of seawater, the highest enrichments are expected during calm winds. An increase in wind speed above $3-4 \mathrm{~m} \mathrm{~s}^{-1}$ will cause a rapid decrease in the enrichment (the Langmuir circula5 tions starts breaking up the slicks), and its effective removal for wind speeds in exceed $8 \mathrm{~m} \mathrm{~s}^{-1}$ (when the wave breaking thoroughly mixes the microlayer with the underlying water). Although there is significant spread in observational data, most of the studies agree that slicks in the open ocean are only observed for surface wind speed $<5 \mathrm{~m} \mathrm{~s}^{-1}$ (Romano, 1996). When winds increase from 2 to $5 \mathrm{~m} \mathrm{~s}^{-1}$, there is an increase in the 10 formation of gaps and a decrease in the satellite-derived areal extent of ocean slicks (Marmorino et al., 2008). This increase of gaps and subsequent decrease in slick coverage is consistent with the Dysthe (2006) model describing the tearing of a surface film in a region of positive surface straining from Langmuir circulations (Langmuir, 1938; Leibovich, 1983). Many studies also report a decrease in microlayer (non-slick organic layer of moderate enrichment) concentration relative to the underlying seawater for surface wind speeds in excess of $\sim 4 \mathrm{~m} \mathrm{~s}^{-1}$ (Obernosterer et al., 2008), except for Wurl et al. (2010) who report constant microlayer surfactant enrichment for winds up to $5.5 \mathrm{~m} \mathrm{~s}^{-1}$, with enrichment persisting for winds up to $10 \mathrm{~m} \mathrm{~s}^{-1}$. When surface winds exceed $8 \mathrm{~m} \mathrm{~s}^{-1}$, the initiation of wave breaking is expected to cause the destruction of the microlayer by mixing it into the underlying seawater (Carlson, 1983). Extrapolation of the linear decrease in microlayer thickness with wind speed observed by Liu and Dickhut (1998) predicts a microlayer thickness of $0 \mu \mathrm{m}$ at a wind speed of $\sim 8.5 \mathrm{~m} \mathrm{~s}^{-1}$, consistent with this picture. At wind speeds in excess of $\sim 11 \mathrm{~m} \mathrm{~s}^{-1}$, the mechanism for sea spray generation is via mechanical disruption of wave crests (e.g., Andreas, 1998 and references therein). The spume drops torn from the wave crests consequently have composition of bulk seawater with little enrichment. Overall, review of published studies indicates that surface wind speed can play a crucial role in determining the physical and chemical characteristics of the air-sea interface and thus the organic enrichment of sea spray.
ACPD

$11,10525-10555,2011$

\section{Wind speed dependent size-resolved parameterization}

B. Gantt et al.

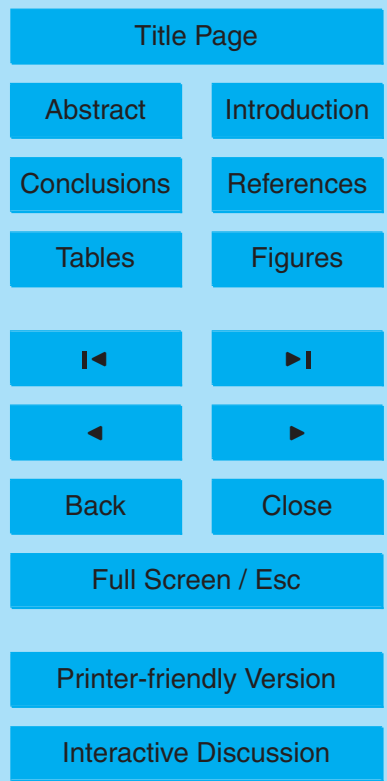


In addition to the potential impact from wind speed, the organic enrichment of sea spray has been shown to be affected by the chemical composition of seawater. Past studies have consistently found that the marine aerosol OC concentration is higher over regions of high biological activity (O'Dowd et al., 2004; Sciare et al., 2009; Miyazaki 5 et al., 2010). The results of multiple ambient and laboratory studies indicated that the upwind concentrations of [Chl-a], [POC], and [DOC] can be used as a proxy for the organic enrichment of sea spray (Gershey, 1983a, b; Hoffman and Duce, 1976; O'Dowd et al., 2004, 2008; Russell et al., 2010).

Several attempts to quantify and characterize size-dependent chemical composition 10 of sea spray aerosols have recently been carried out. These measurements consistently have shown that the organic mass fraction of submicron sea spray increases with decreasing particle size (Oppo et al., 1999; Keene et al., 2007; Facchini et al., 2008), with a small and relatively constant organic fraction for supermicron particles with aerodynamic diameter $<10 \mu \mathrm{m}$ (Oppo et al., 1999; Keene et al., 2007; Facchini 15 et al., 2008). Keene et al. (2007) reported that the water soluble organic carbon of artificially generated aerosols within a chamber was highly enriched in all aerosol size fractions, with greatest enrichments in size fraction with geometric mean diameter of $0.13 \mu \mathrm{m}$. In this smallest size fraction sampled, organic carbon comprised up to $80 \%$ of aerosol mass and dominated the mass of most individual particles (Keene et al., 2007). Facchini et al. (2008) similarly reported a high contribution of organic matter in submicron sea spray particles (up to $77 \pm 5 \%$ in the $0.125-0.25 \mu \mathrm{m}$ size range). However, their analysis discriminated between water soluble and insoluble organic carbon (WSOC and WIOC, respectively), finding a dominant contribution (up to $94 \pm 4 \%$ ) from the water insoluble fraction.

Despite the likely impact of both meteorological factors and chemical composition of seawater on sea spray chemistry, most of the recent parameterizations of marine POA emissions use only [Chl-a] as a proxy for deriving the organic mass fraction of sea spray aerosols (O'Dowd et al., 2008) or for determining the total magnitude of the emissions (Spracklen et al., 2008). In this paper, we develop a new parameterization
11, 10525-10555, 2011

\section{Wind speed dependent size-resolved parameterization}

B. Gantt et al.

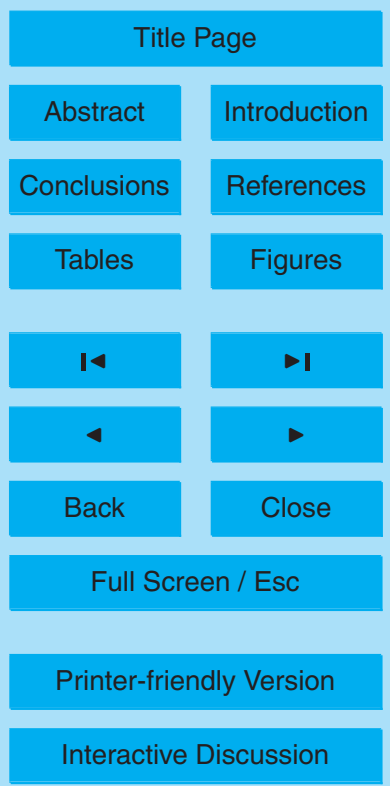


for organic fraction of sea spray aerosol based on the conceptual picture of Fig. 1, and constrain it using ambient data from two different oceanic regions.

\section{Data and methods}

\subsection{Aerosol chemistry}

5 Two coastal stations with long-term measurements of aerosol chemistry were selected for this study; the Mace Head Atmospheric Research Station $\left(53.33^{\circ} \mathrm{N}, 9.90^{\circ} \mathrm{W}\right)$ on the Atlantic coast of Ireland and a site at the Point Reyes National Seashore $\left(38.12^{\circ} \mathrm{N}\right.$, $122.91^{\circ} \mathrm{W}$ ) on the Pacific coast of California. Measurements of the $\sim 50-100 \mathrm{~h}$ average chemical composition of aerosols with an aerodynamic diameter $<1.5 \mu \mathrm{m}$ from Mace

10 Head (Cavalli et al., 2004; Yoon et al., 2007) have been supplemented with measurements of the chemical composition of aerosols with diameters $<2.5 \mu \mathrm{m}$ at Point Reyes near San Francisco, CA taken as part of the United States' Interagency Monitoring of Protected Visual Environments (IMPROVE) network (http://vista.cira.colostate.edu/ improve/). At Point Reyes, aerosols are captured on filters for 24 hours (midnight to 15 midnight local time) every 3 days and analyzed for chemical composition. Point Reyes was selected from the large (170 stations) IMPROVE monitoring network because it is located very close to the coast $(\sim 4 \mathrm{~km})$ and has the highest frequency of aerosols exhibiting marine characteristics (White, 2008).

Several compounds are included in the analysis of aerosol chemical composition, including elemental carbon (EC), OC, and sodium ( $\mathrm{Na}$ ). To avoid potential problems with $\mathrm{Na}$ measurements (White, 2008), the data at Point Reyes were analyzed for the years 2000-2001 and 2005-2007. For Mace Head, the aerosol concentrations measurements conducted only during periods of "clean sector" conditions (wind direction from $180^{\circ}$ to $300^{\circ}$, particle concentration $<700 \mathrm{~cm}^{-3}, \mathrm{EC}<0.05 \mu \mathrm{g} \mathrm{m}^{-3}$ ) for the years 2002 to 2006 are included in the analysis. The OC measurements from Mace Head are further separated into WSOC and WIOC following Cavalli et al. (2004). Unlike

\section{Wind speed dependent size-resolved parameterization}

B. Gantt et al.

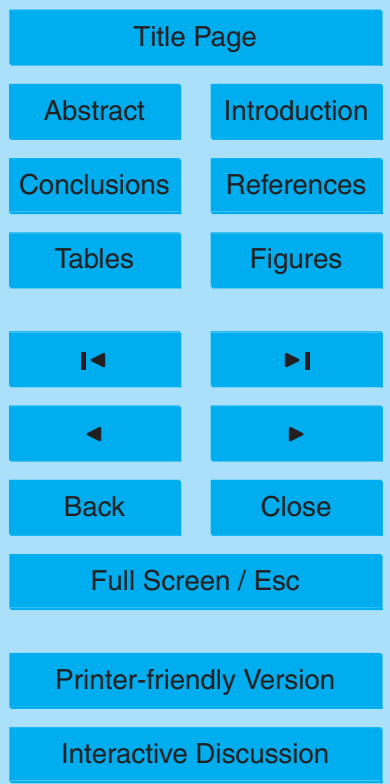


Mace Head, OC measurements obtained from the IMPROVE network do not segregate WSOC and WIOC. To be consistent with the Mace Head data, it was assumed that $70 \%$ of the OC measured at Point Reyes is insoluble. This WIOC/OC fraction was similar to that observed at Mace Head (Cavalli et al., 2004; O'Dowd et al., 2004) and

5 Amsterdam Island $\left(37.80^{\circ} \mathrm{S}, 77.57^{\circ} \mathrm{E}\right.$ ) (Sciare et al. 2009) during the summer when $\mathrm{OC}$ concentrations were highest. The organic mass fraction of sea spray $\left(\mathrm{OM}_{\mathrm{sS}}\right)$ can then be determined by converting the $\mathrm{OC}$ measurements to organic matter (OM) using a $1.4 \mathrm{OM} / \mathrm{OC}$ ratio (Descari et al., 2007; Facchini et al., 2008) and using the equation $\mathrm{OM}_{\mathrm{ss}}=\mathrm{WIOM} /(\mathrm{WIOM}+$ sea-salt) first employed in O'Dowd et al. (2008), where sea-salt 10 is estimated as $\mathrm{Na} / 0.3061$ corresponding to the mass fraction of sodium in dry sea-salt (Seinfeld and Pandis, 2006). $\mathrm{OM}_{\mathrm{ss}}$ is used here as the primary variable of the analysis because it is independent of the sea spray concentration (considering that POA of marine origin and sea-salt have similar production mechanisms and sinks) and can be easily applied to published sea spray emission parameterizations.

\subsection{Meteorology}

Wind speed and direction data used in the analysis is different for the two stations. At Mace Head, $10 \mathrm{~m}$ wind speed and direction was measured at the same location as the aerosol measurements, with the speed recorded only during periods when aerosols were being measured. At Point Reyes, hourly wind speed and direction at $5 \mathrm{~m}$ was 20 measured at the Bodega Bay buoy \#46013 $\left(38.24^{\circ} \mathrm{N} 123.30^{\circ} \mathrm{W}\right)$ as part of the United States' National Data Buoy Center network (http://www.ndbc.noaa.gov/). This buoy is located $\sim 37 \mathrm{~km}$ west of Point Reyes in the Pacific Ocean. The $5 \mathrm{~m}$ wind speed was converted to $10 \mathrm{~m}$ using the power-law wind-profile as follows: $U_{10}=U_{5}\left(\frac{10}{5}\right)^{0.11}$ (Hsu et al., 1994). In order to make the aerosol measurements between the two sites 25 more comparable, a wind direction filter was used on the Point Reyes data including only days with all $24 \mathrm{~h}$ having onshore wind directions (between $180^{\circ}$ and $315^{\circ}$ ). Such rigorous filtering reduced the number of qualifying days from 365 to 36 . Further filtering of the Point Reyes aerosol measurements included only days with $\mathrm{EC}<0.05 \mathrm{\mu g} \mathrm{m}^{-3}$ in

\section{Wind speed dependent size-resolved parameterization}

B. Gantt et al.

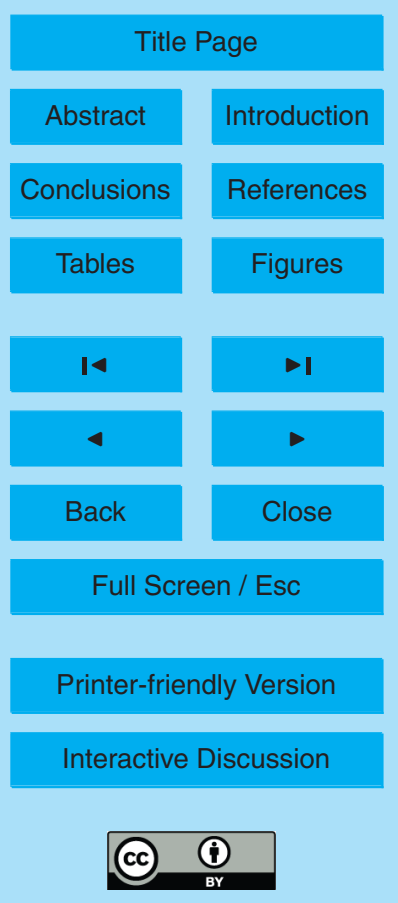


order to avoid potential influence of OM from anthropogenic sources (Clarke, 1989) and to make them consistent with the Mace Head clean sector data.

\subsection{Ocean chemistry}

The oceanic parameters derived from satellite data include 8-day average Level 3 surface [Chl-a], [POC], and [DOC] from the Sea Wide Field-of-view Sensor (SeaWiFS) for the years 2000-2007. [Chl-a] is determined using the OC4v4 algorithm (O'Reilly et al., $1998,2000)$, and [POC] was calculated from normalized water-leaving radiances at 443,490 , and $555 \mathrm{~nm}$ using the method of Stramska et al. (2009). In order to estimate the ocean [DOC] distribution, a sea surface temperature (SST)-based approach (Siegel et al., 2002) and a colored dissolved organic matter (CDOM)-based approach (Mannino et al., 2008) were combined to generate the estimates of surface layer [DOC] for the years 2000-2007. The 8-day average SST data was obtained from Moderate Resolution Imaging Spectroradiometer (MODIS), and the 8-day average normalized water leaving radiance data at 490 and $555 \mathrm{~nm}$ (required for the CDOM-based approach) were retrieved from SeaWiFS. As each method is designed to estimate the [DOC] in different parts of the ocean, the SST-based approach was used for the open ocean and the CDOM-based approach was used for coastal waters (Siegel et al., 2002; Mannino et al., 2008). All of the satellite-derived data was regridded to $1^{\circ} \times 1^{\circ}$ spatial resolution. The reported global root mean squared error of the [Chl-a], [POC], and [DOC] 20 were $\sim 0.2 \mathrm{mg} \mathrm{m}^{-3}, 20 \mathrm{mg} \mathrm{m}^{-3}$, and 2.6-8.6 $\mu_{\mathrm{mol} \mathrm{L}}^{-1}$, respectively (Siegel et al., 2005; Stramska et al., 2009; Mannino et al., 2008; Siegel et al., 2002). For each aerosol measurement, a non-weighted upwind average of the temporally-collocated [Chl-a], $[D O C]$ and $[P O C]$ was calculated using 24-h back-trajectories based on the observed wind speed and direction (grouped into $45^{\circ}$ vectors).

\section{Wind speed dependent size-resolved parameterization}

B. Gantt et al.

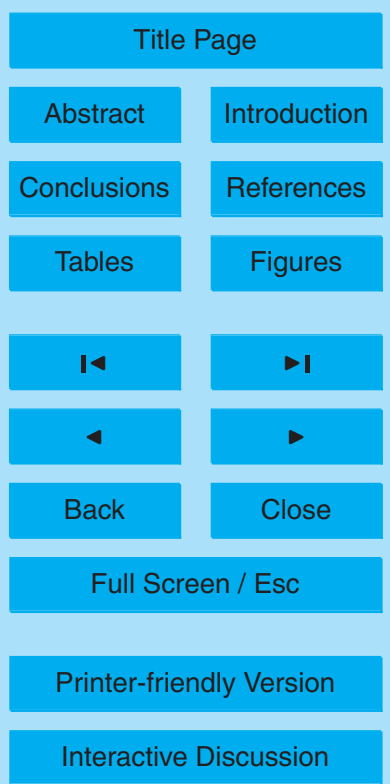




\section{Results and discussion}

\subsection{Factors affecting organics in sea spray}

\subsubsection{Wind speed}

A plot of organic carbon fraction against surface wind speed in Fig. 2a shows that for both the Mace Head and Point Reyes measurement stations, the $\mathrm{OM}_{\mathrm{ss}}$ decreases with increasing $10 \mathrm{~m}$ wind speed in a manner consistent with our conceptual picture given on Fig. 1. For wind speeds above $10 \mathrm{~m} \mathrm{~s}^{-1}$, sea spray aerosols are largely composed of sea-salt with very little contribution from organics. As wind speeds decrease to $5 \mathrm{~m} \mathrm{~s}^{-1}$, a strong increase in the organic fraction of sea spray was observed. This trend can be explained by the presence of a surface microlayer described by our conceptual wind speed-organic enrichment relationship. No data exists for surface winds of less than $4 \mathrm{~m} \mathrm{~s}^{-1}$ due to longer averaging time at the two stations (Mace Head data was typically averaged over $50-100 \mathrm{~h}$ and Point Reyes over $24 \mathrm{~h}$ ). However, considering that wind speed of $\geq 4 \mathrm{~m} \mathrm{~s}^{-1}$ is typically associated with the onset of bubble formation (Monahan and O'Muircheartaigh, 1986), enrichment at wind speed values lower than that may not be environmentally relevant. Nevertheless, our conceptual picture on Fig. 1 predicts that $\mathrm{OM}_{\mathrm{ss}}$ should plateau at a wind speed value of $\sim 3 \mathrm{~m} \mathrm{~s}^{-1}$. Using the MATLAB curve fitting tool and the proposed conceptual relationship, we have developed a logistic function that is a good fit $\left(R^{2}=0.38-0.47\right)$ for the existing ambient measurements

enrichment and wind speed shown on Fig. 2a suggests that winds (through their effect on air-sea interface) may play a considerable role in the enrichment of sea spray aerosol.

\section{Wind speed dependent size-resolved parameterization}

B. Gantt et al.

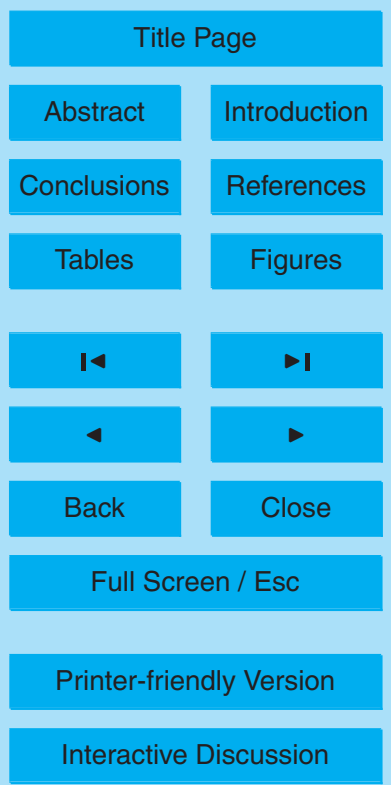




\subsubsection{Ocean chemistry}

Analysis of ambient marine aerosol chemical composition suggests that there is a maximum enrichment of sea spray aerosols by organics that, although usually occurring at low wind speed, can be vastly different for different measurement locations. Figures $2 b-d$ show that each ocean chemistry parameter examined ([POC], [DOC], and [Chl-a]) had a positive relationship with $\mathrm{OM}_{\mathrm{ss}}$. It is worth noting that the relationship between $\mathrm{OM}_{\mathrm{ss}}$ and [POC] (Fig. 2c) was stronger than [DOC] (Fig. 2d) for Mace Head, consistent with the hypothesis of Russell et al. (2010) that [POC] influences organic enrichment of Northern Atlantic sea spray aerosols. Overall, out of the three ocean parameters examined, the strongest and most consistent relationship was found between $\mathrm{OM}_{\mathrm{ss}}$ and [Chl-a] (Fig. 2b). Therefore, in our new parameterization of the organic carbon fraction of sea spray, [Chl-a] was chosen as a proxy for the ocean chemistry. Using the MATLAB surface fitting tool and a general multi-variable logistic equation, the combined relationships of $\mathrm{OM}_{\mathrm{ss}}$ vs. $U_{10}$ and $\mathrm{OM}_{\mathrm{ss}}$ vs. [Chl-a] were found to be very similar for both stations. The corresponding coefficients in each equation were averaged to yield:

$\mathrm{OM}_{\mathrm{ss}}\left(\mathrm{Chl}-\mathrm{a}, U_{10}\right)=\frac{\mathrm{OM}_{\mathrm{ss}}^{\max }}{1+\exp \left(-2.63[\mathrm{Chl}-a]+0.18 U_{10}\right)}$

where [Chl-a] is in units of $\mathrm{mg} \mathrm{m}^{-3}$ and $U_{10}$ is in units of $\mathrm{m} \mathrm{s}^{-1}$. The magnitudedetermining numerator of the equation, $\mathrm{OM}_{\mathrm{ss}}^{\max }$, is the maximum $\mathrm{OM}_{\mathrm{ss}}$ observed at the two sites during the entire measurement period ( 0.24 for Point Reyes and 0.78 for Mace Head). When compared to measurement data, the $R^{2}$ value for Eq. (1) is $\sim 0.52$ and 0.56 at Point Reyes and Mace Head, respectively (see Fig S1 for scatterplot). A $3-D$ visualization of Eq. (2) in Fig. 3 shows the interdependence of [Chl-a] and $U_{10}$ in determining $\mathrm{OM}_{\mathrm{ss}}$, where the steepest slope corresponding to highest sensitivity occurs in the intermediate [Chl-a] and $U_{10}$ values and the shallowest slopes (constant $\mathrm{OM}_{\mathrm{SS}}$ ) occur at the extreme values where $[\mathrm{Chl}-\mathrm{a}]>1 \mathrm{mg} \mathrm{m}^{-3}$ and $U_{10}>1.5 \mathrm{~m} \mathrm{~s}^{-1}$. Despite the

\section{Wind speed dependent size-resolved parameterization}

B. Gantt et al.

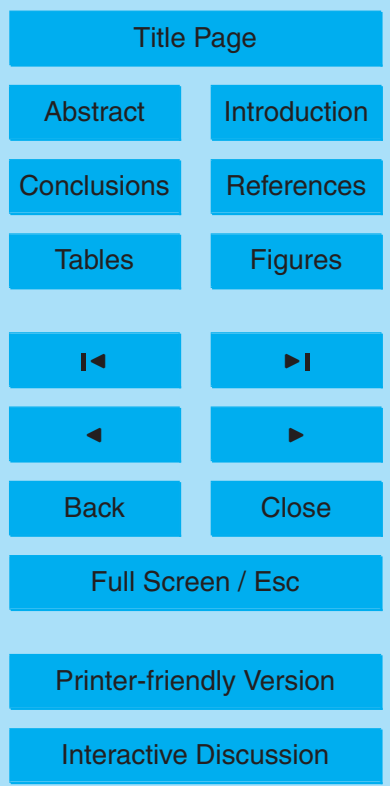


relationship between [Chl-a] and wind speed that exists because of seasonal effects (high [Chl-a] and low winds in summer, low [Chl-a] and high winds in winter), the inverse relationship between $\mathrm{OM}_{\mathrm{ss}}$ and $U_{10}$ remains even when the measurements are binned into "low", "moderate" and "high" [Chl-a] regimes (see Fig. S2). Comparison of

5 Eq. (1) with the high organic aerosol concentration episode at Mace Head described in Ovadnevaite et al. (2011) reveals remarkably good agreement, with an observed and predicted $\mathrm{OM}_{\mathrm{ss}}$ of 0.57 and 0.54 , respectively (assuming $U_{10}=10 \mathrm{~m} \mathrm{~s}^{-1}$ and [Chla] $=1 \mathrm{mg} \mathrm{m}^{-3}$ based on Table 1 and Fig. 1 from Ovadnevaite et al., 2011).

The differences between the relationship in Eq. (1) and those of previous parameter10 izations are greatest at high and low wind speeds. For a given [Chl-a], our equivalent submicron $\mathrm{OM}_{\mathrm{ss}}$ will typically be lower than that of O'Dowd et al. (2008) and Viganti et al. (2010) for strong winds and higher for low wind conditions.

\subsubsection{Aerosol size}

The different aerosol sizes ( $<1.5 \mu \mathrm{m}$ from Mace Head and $<2.5 \mu \mathrm{m}$ at Point Reyes) 15 measured at each site were likely to contribute to the differences in $\mathrm{OM}_{\mathrm{ss}}^{\max }$. Since neither the Mace Head nor Point Reyes datasets we used had size-resolved aerosol composition, to better constrain $\mathrm{OM}_{\mathrm{ss}}$ as a function of aerosol size we used published measurements of the size-resolved organic mass fraction of aerosols generated from bubble-bursting of seawater over the biologically-active Northern Atlantic (Facchini et al., 2008). Figure 4 shows the $\mathrm{OM}_{\mathrm{ss}}$ measurements from Facchini et al. (2008) fitted by the following equation:

$\mathrm{OM}_{\mathrm{ss}}\left(D_{\mathrm{p}}\right)=\frac{\mathrm{OM}_{\mathrm{ss}}^{\max }\left(D_{\mathrm{p}}\right)}{1+0.03 \exp \left(6.81 D_{\mathrm{p}}\right)}+\mathrm{OM}_{\mathrm{ss}}^{\min }\left(D_{\mathrm{p}}\right)$

where $D_{\mathrm{p}}$ is the ambient $(\mathrm{RH}=80 \pm 8 \%)$ aerosol aerodynamic diameter in micrometers, and $\mathrm{OM}_{\mathrm{ss}}^{\max }\left(D_{\mathrm{p}}\right)$ and $\mathrm{OM}_{\mathrm{ss}}^{\min }\left(D_{\mathrm{p}}\right)$ are size-dependent maximum and minimum organic carbon fraction of sea spray with values of 0.82 and 0.03 , respectively.

\section{Wind speed dependent size-resolved parameterization}

B. Gantt et al.

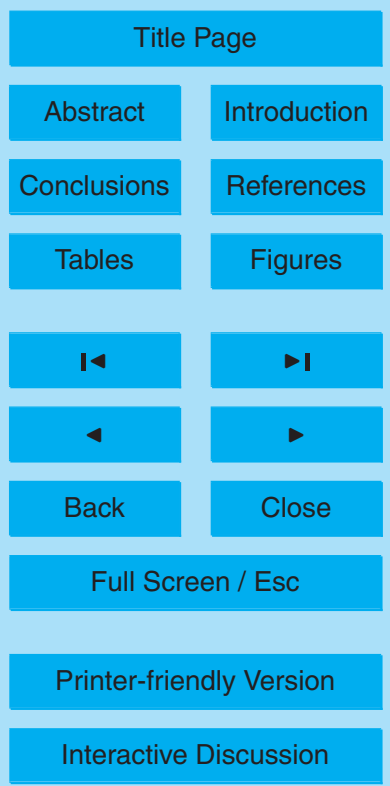


Our size-dependent organic enrichment is consistent with other measurements/parameterizations. Size-resolved measurements from Keene et al. (2007) give similar results for the organic fraction of sea spray, but the reported OC as only water soluble is potentially incompatible with the data from Mace Head. Both Oppo et 5 al. (1999) and Long et al. (2011) describe similar size-dependent organic enrichment of sea spray through adsorption models.

\subsubsection{Combination of wind speed, [Chl-a], and aerosol size}

To create an $\mathrm{OM}_{\mathrm{ss}}$ equation as a function of [Chl-a], $U_{10}$, and sea spray size, we have combined Eqs. (1) and (2) in a way that retains the size dependence of $\mathrm{OM}_{\mathrm{ss}}$ 10 from Eq. (2) but scales with [Chl-a] and $U_{10}$ as described in Eq. (1). Specifically, the $\mathrm{OM}_{\mathrm{sS}}^{\max }\left(D_{\mathrm{p}}\right)$ and $\mathrm{OM}_{\mathrm{ss}}^{\min }\left(D_{\mathrm{p}}\right)$ values from Eq. (2) were scaled with the $\mathrm{OM}_{\mathrm{ss}}$ from Eq. (1) after setting $\operatorname{OM}_{\mathrm{ss}}^{\max }\left(D_{\mathrm{p}}\right)$ to 1 reflecting the highest potential enrichment in the organic fraction (Bigg and Leck, 2008). This allows the size dependence from biologicallyactive Northern Atlantic (Facchini et al., 2008) region to be globally applicable to areas with vastly different winds and $[\mathrm{Chl}-a]$. The resulting final $\mathrm{OM}_{\mathrm{ss}}$ parameterization is:

$\mathrm{OM}_{\mathrm{ss}}\left(\mathrm{Chl}-\mathrm{a}, U_{10}, D_{\mathrm{p}}\right)=\frac{\frac{1}{1+\exp \left(-2.63[\mathrm{Chl}-\mathrm{a}]+0.18 U_{10}\right)}}{1+0.03 \exp \left(6.81 D_{\mathrm{p}}\right)}+\frac{0.03}{1+\exp \left(-2.63[\mathrm{Chl}-\mathrm{a}]+0.18 U_{10}\right)}$

There are two main advantages of Eq. (3): (i) it does not require any artificial cutoffs of wind speed or [Chl-a] and (ii) it can give the size-resolved organic carbon fraction of sea spray aerosols from globally-available $U_{10}$ and [Chl-a] data. Figure 5 examines the dependence of $\mathrm{OM}_{\mathrm{ss}}$ on three parameters: sea spray size $\left(D_{\mathrm{p}}\right)$, chemical composition of ocean seawater ([Chl-a]) and physical mechanism of aerosol emission $\left(U_{10}\right)$ described by Eq. (3). To make the dependence of $\mathrm{OM}_{\mathrm{ss}}$ on all three parameters easily visible, we have selected three different aerosol diameters roughly corresponding to typical marine aerosol Aitken, accumulation, and coarse mode diameters (Yoon et al., 25 2007). According to Fig. 5, $\mathrm{OM}_{\mathrm{SS}}$ increases for higher ocean biological productivity and

\section{Wind speed dependent size-resolved parameterization}

B. Gantt et al.

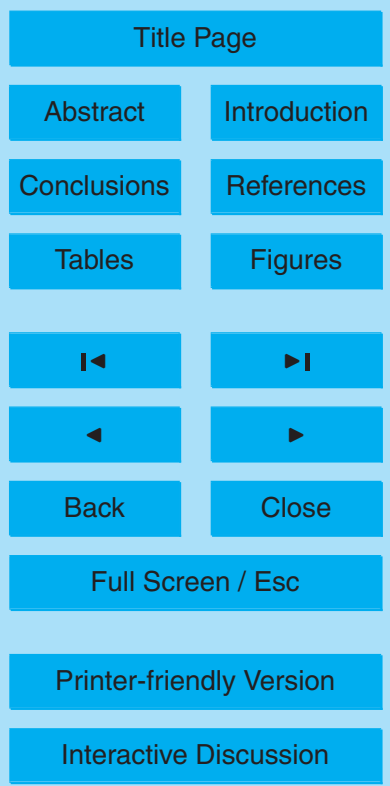


lower wind speed and shows very strong dependence on aerosol size. These general trends are non-linear; changes in $\mathrm{OM}_{\mathrm{ss}}$ occur rapidly at moderate wind speed and [Chl-a] and more slowly at the extremes due to the plateaus found in the logistic curve. Our calculations suggest that there is little difference between the maximum organic

5 fraction of the Aitken and accumulation mode aerosols $(\sim 0.8-0.9)$, while the coarse mode maximum organic fraction is substantially lower $(<0.02)$ due to the increasing dominance of sea-salt in these particles.

\subsection{Estimated emission rate}

To estimate marine POA fluxes in different parts of the oceans, we have used 10 Mårtensson et al. (2003) and Gong (2003) sea spray functions with hourly averaged $U_{10}$ calculated by the Community Atmosphere Model (CAM5) (Collins et al., 2006) and monthly-averaged climatological [Chl-a] retrieved by SeaWiFS. The Mårtensson et al. (2003) function was used for dry particle diameters ranging from $\sim 0.02$ to $2.8 \mu \mathrm{m}$ and the Gong (2003) function for diameters from 2.8 to $20 \mu \mathrm{m}$. Both the Mårtensson et al. (2003) and Gong et al. (2003) functions are assumed to represent sea spray aerosols whose effective densities are determined by the fractional contribution of sea-salt and organics. Since the magnitude of $\mathrm{OM}_{\mathrm{ss}}$ can potentially influence the hygroscopicity of the aerosol, a conversion between dry and ambient aerosol diameters was achieved by changing the $\mathrm{OM}_{\mathrm{ss}}$ from Eq. (3) to an organic volume frac20 tion $\left(\rho_{\text {organic }}=1 \mathrm{~g} \mathrm{~cm}^{-3}\right.$ and $\rho_{\mathrm{NaCl}}=2.165 \mathrm{~g} \mathrm{~cm}^{-3}$ ) and using it to estimate the resulting hygroscopicity (kappa $-k$ ) values. The growth factor (GF) was derived at ambient $\mathrm{RH}=80 \%$ for the combined organic-inorganic particle by assuming $\kappa_{\text {organic }}=0$ and $\kappa_{\mathrm{NaCl}}=1.12$ (Petters and Kreidenweis, 2007). Figure 6 shows the global annual submicron (dry aerosol diameter $<1 \mu \mathrm{m}$ ) marine primary organic aerosol emission rate, with 25 the highest emissions occurring over the mid latitude waters $\left(30-60^{\circ} \mathrm{N}\right.$ and $\left.30-60^{\circ} \mathrm{S}\right)$ where strong winds and high [Chl-a] are common throughout the year. Despite having a low $\mathrm{OM}_{\mathrm{ss}}$, areas with strong winds and low [Chl-a] still have moderate marine POA emissions due to the exponential wind speed dependence of sea spray emissions.

\section{Wind speed dependent size-resolved parameterization}

B. Gantt et al.

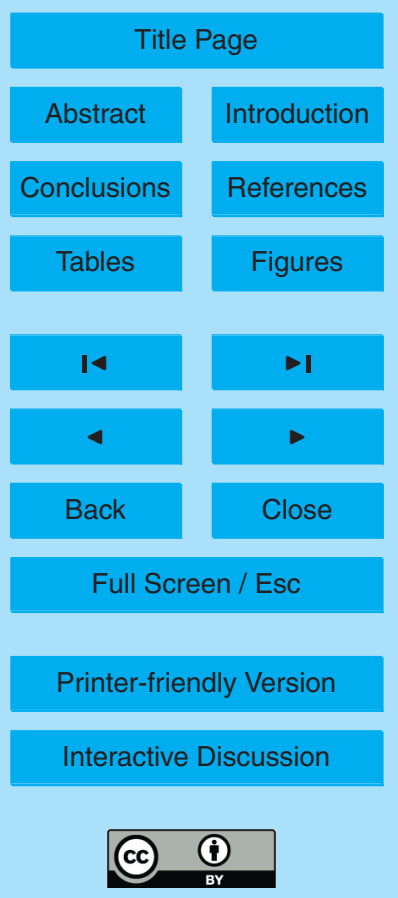


The predicted emission rates in tropical oceanic regions, however, are larger than those from previous studies (Vignati et al., 2010; Langmann et al., 2008; Gantt et al., 2009). As there have been relatively few aerosol measurements from tropical oceanic regions, the predicted organic emission rates are difficult to verify. The global magni-

5 tude of submicron marine POA emissions in this study is $2.8 \mathrm{Tg} \mathrm{Cyr}^{-1}$, with emissions up to $5.6 \mathrm{Tg} \mathrm{Cyr}^{-1}$ when using a growth factor of aerosols composed of $100 \%$ organic $(G F=1)$. In this later formation, a GF of 1 effectively assumes that the aerosol diameter measurements of Facchini et al. (2008) thus the $D_{p}$ in Eq. (2) represents the dry aerosol diameter. This assumption is not unreasonable due to some drying from 10 the pressure drop going down the stages of the Berner impactor used in Facchini et al. (2008). The measurements of Facchini et al. (2008) did not extend as far into the coarse mode as the model, so our estimated total global marine POA emission rate of $15.9 \mathrm{TgC} \mathrm{yr}^{-1}$ (up to $18.7 \mathrm{TgC} \mathrm{yr}^{-1}$ when using a growth factor of (1) is highly uncertain. The considerable organic enrichment in the largest aerosol size fraction (up to

$40 \%$ of aerosol mass) reported in size-dependent measurements of Keene et al. (2007) suggests that this value could be a low estimate.

\section{Caveats and uncertainty}

One of the main caveats in our study arises from the use of observed or estimated WIOC at a few coastal sites as a proxy for global marine POA. To derive chemical 20 composition of the organic fraction of sea spray, we have used values reported by Facchini et al. (2008) which reported a high contribution (up to $77 \pm 5 \%$ ) of organic matter in small diameter sea spray particles. Although this large organic contribution was also observed by Keene et al. (2007), such high fractions of organics have not been found in all locations (Modini et al., 2010). Additionally, the WIOC/OC ratio used for the Point Reyes data is also uncertain as not all sites have observed this ratio (Miyazaki et al., 2010). At Mace Head, long term measurements have revealed that this ratio is not consistently observed (Rinaldi et al., 2010).

\section{ACPD}

$11,10525-10555,2011$

\section{Wind speed dependent size-resolved parameterization}

B. Gantt et al.

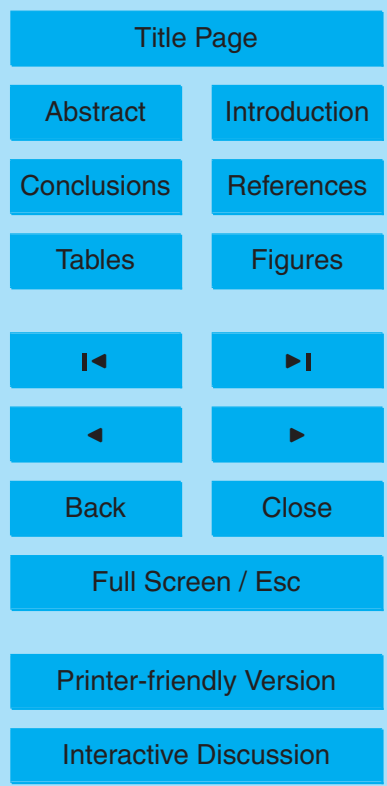


Coastal sites also suffer from uncertainties related to the influence of the surf zone and continental aerosols. Even though sea spray aerosol production by surf-zone wave breaking were shown to be 1-2 orders of magnitude higher than that of the open ocean (de Leeuw et al., 2000; Vignati et al., 2001), previous studies have suggested that 5 aerosol chemical composition and flux parameterizations derived from coastal measurements can provide a suitable proxy for open ocean conditions and therefore can been successfully used for global emissions assessments (Clarke, 2006; Rinaldi et al., 2009). The use of wind speed measurements near the aerosol sampling location for both the Point Reyes and Mace Head sites also leads to some uncertainty due 10 to the size of the concentration footprint from which the sea spray is emitted. Ceburnis et al. (2008) describes that while the flux footprint of the Mace Head station is typically within $5 \mathrm{~km}$, the concentration footprint can be 10-100 times further upwind. We feel as though this uncertainty does not result in large errors in the magnitude and direction of our wind speed dependence because of the similarity between Mace 15 Head nearshore and offshore wind speeds derived from NASA's Quick Scatterometer (QuikSCAT) (see Fig. S3) when averaged over the 50-100 h sampling period. Continental sources can also potentially contribute to $\mathrm{OM}_{\mathrm{sS}}$ measurements at marine sites (Turekian et al., 2003), though it is expected such sources to be minor in this study due to the very long (thousands of kilometers) upwind fetch of open ocean at both sites and evidence from a recent study that $80 \%$ of the onshore flow organic aerosols at Mace Head had a marine source (Ceburnis et al., 2011). These inconsistencies and uncertainties highlight the difficulty in confidently applying our organic sea spray parameterization (derived using limited spatiotemporal measurements) to the global scale.

25 Moreover, when we compared our conceptual model to measurement data from Mace Head and Point Reyes, we assumed consistency between measured or estimated WIOM and POA. Such an assumption may lead to additional uncertainty in marine POA emissions, as it disregards the fraction marine SOA that may be water insoluble or POA that is water soluble (even though these contributions are expected

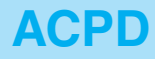

$11,10525-10555,2011$

\section{Wind speed dependent size-resolved parameterization}

B. Gantt et al.

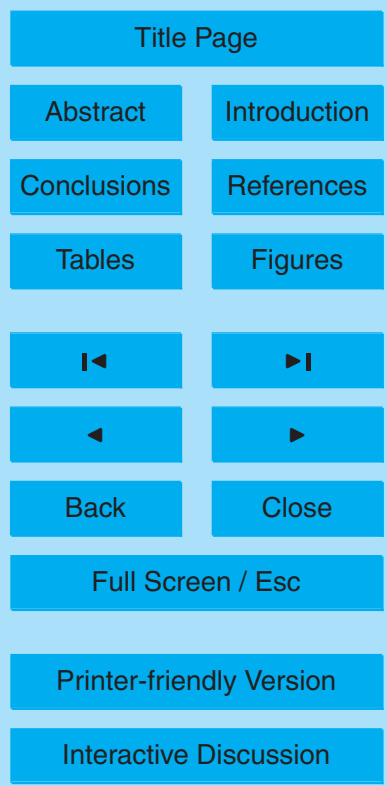


to be minimal). The well recognized SOA component of marine aerosol derived from ocean-emitted BVOCs is methanesulfonate $\left(\mathrm{MS}^{-}\right.$) from dimethyl sulfide (Saltzman et al., 1983), but other SOA precursor gases such as biogenic isoprene and monoterpenes emitted from phytoplankton have also been postulated to affect marine organic

5 aerosols (Meskhidze and Nenes, 2006; Gantt et al., 2009; Luo and Yu, 2010). Additionally, oxidation of marine primary $\mathrm{OM}$ has been suggested to lead to the formation of WSOM which has typically been considered to have secondary sources (Ceburnis et al., 2008; Claeys et al., 2009; Rinaldi et al., 2010; Ovadnevaite et al., 2011). Such uncertainty regarding the origin of marine-source primary and secondary organic 10 aerosols and inadequate understanding of marine organic aerosol formation processes adds to the difficulty in estimating marine POA emissions.

\section{Conclusions}

A conceptual relationship between wind speed and sea spray organic mass fraction $\left(\mathrm{OM}_{\mathrm{sS}}\right)$ has been developed and used to calculate marine primary organic aerosol 15 (POA) emissions in different parts of the global oceans. Our analysis predicts the highest enrichments of marine aerosol with organics during calm winds, when large amounts of organic material can accumulate at the sea-surface often forming visible slicks. An increase in wind speed (above $3-4 \mathrm{~m} \mathrm{~s}^{-1}$ ) will initiate Langmuir circulations causing a breakup of the slicks and a rapid decrease in $\mathrm{OM}_{\mathrm{ss}}$. Wave breaking (caused 20 by wind speeds in excess of $8 \mathrm{~m} \mathrm{~s}^{-1}$ ) will thoroughly mix the microlayer with the underlying water, effectively reducing organic enrichment at the air-sea interface and thus in sea spray aerosols. Derived relationships between observed $10 \mathrm{~m}$ wind speed $\left(U_{10}\right)$ and remotely-sensed upwind oceanic concentrations of chlorophyll-a ([Chl-a]), particulate organic carbon ([POC]), and dissolved organic carbon ([DOC]) were compared to 25 aerosol chemical composition from the Mace Head (Atlantic) and Point Reyes (Pacific) coastal sites. Our results indicate that wind speed, [Chl-a], and aerosol size are likely to be the three most important parameters regulating $\mathrm{OM}_{\mathrm{ss}}$.

\section{Wind speed dependent size-resolved parameterization}

B. Gantt et al.

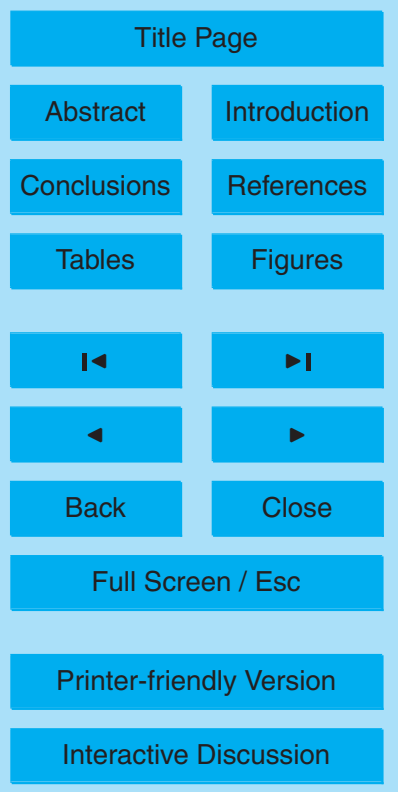


The new empirical parameterization using a logistic fit for the relationship between $\mathrm{OM}_{\mathrm{ss}}$ and [Chl-a], $U_{10}$, and aerosol diameter was then used to calculate size-resolved global marine POA emissions using established sea spray functions. Although our model-predicted submicron marine organic carbon emission rate ranging from 2.8 to $5 \quad 5.6 \mathrm{Tg} \mathrm{Cyr}^{-1}$ is comparable to several recent studies (Spracklen et al., 2008; Vignati et al., 2010), the wind speed dependence of our parameterization gives a distinct spatial distribution. The exponential wind speed dependence of the sea spray function leads to the highest marine POA emissions in areas with strong winds; however, we also predict moderate emissions widespread throughout the global oceans due to the 10 inverse relationship between wind speed and $\mathrm{OM}_{\mathrm{ss}}$. Our parameterization suggests that oceanic regions with high biological productivity are more likely to have higher marine POA emissions than areas with low productivity. Additional comparative modeling analysis of different marine POA emission schemes, combined with long-term measurements of marine aerosol concentration in previously under-sampled areas (i.e., 15 tropical oceans), is needed to determine the accuracy of this marine organic aerosol emission parameterization.

\section{Supplementary material related to this article is available online at: http://www.atmos-chem-phys-discuss.net/11/10525/2011/ acpd-11-10525-2011-supplement.pdf.}

Acknowledgements. This research was supported by the Office of Science (BER), U.S. Department of Energy, Grant No. DE-FG02-08ER64508 and a NASA NESSF fellowship. The authors would like to thank Markus Petters and Jurgita Ovadnevaite for helpful discussion and suggestions. The experimental work performed at Mace Head was supported by the EU Project MAP (Marine Aerosol Production), the EPA Ireland project EASI-AQCIS (Exchange at the Air-Sea Interface: Air Quality \& Climate ImpactS), and HEA PRTLI4. ACCENT (Atmospheric Composition Change the European Network of Excellence) is also gratefully acknowledged.

\section{ACPD}

$11,10525-10555,2011$

\section{Wind speed dependent size-resolved parameterization}

B. Gantt et al.

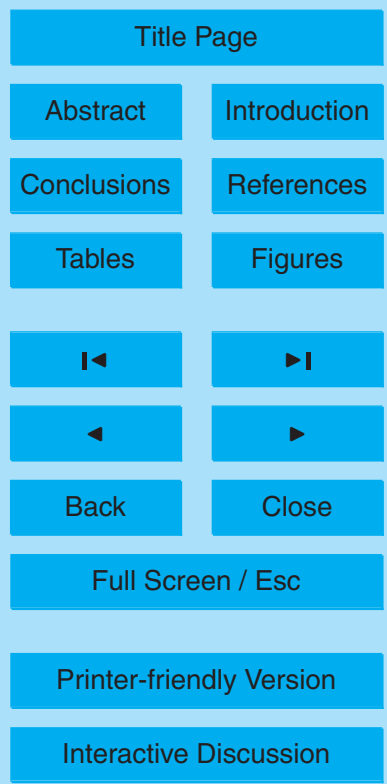




\section{References}

Andreae, M. O.: Aerosols before pollution, Science, 315, 50-51, 2007.

Andreas, E. L.: A new sea spray generation function for wind speeds up to $32 \mathrm{~m} \mathrm{~s}^{-1}$, J. Phys. Oceanogr., 28, 2175-2184, 1998.

Bigg, E. K. and Leck, C.: The composition of fragments of bubbles bursting at the ocean surface, J. Geophys. Res., 113(D1), 1209, doi:10.1029/2007JD009078, 2008.

Blanchard, D. C.: Sea-to-air transport of surface active material, Science, 146, 396-397, doi:10.1126/science.146.3642.396, 1964.

Bony, S. and Dufresne J.-L.: Marine boundary layer clouds at the heart of tropical cloud feedback uncertainties in climate models, Geophys. Res. Lett., 32, L20806, doi:10.1029/2005GL023851, 2005.

Carlson, D. J.: Dissolved organic materials in surface microlayers: Temporal and spatial variability and relation to sea state, Limnol. Oceanogr., 28, 415-431, 1983.

Cavalli, F., Facchini, M. C., Decesari, S., Mircea, M., Emblico, L., Fuzzi, S., Ceburnis, D., Yoon,

15 Y. J., O'Dowd, C. D., Putaud, J. P., and Dell'Acqua, A.: Advances in characterization of sizeresolved organic matter in marine aerosol over the North Atlantic, J. Geophys. Res.-Atmos., 109, D24215, doi:10.1029/2004JD005137, 2004.

Ceburnis, D., O'Dowd, C. D., Jennings, G. S., Facchini, M. C., Emblico, L., Decesari, S., Fuzzi, S., and Sakalys, J.: Marine aerosol chemistry gradients: elucidating primary and secondary processes and fluxes, Geophys. Res. Lett., 35, L07804, doi:10.1029/2008GL033462, 2008.

Ceburnis, D., Garbaras, A., Szidat, S., Rinaldi, M., Fahrni, S., Perron, N., Wacker, L., Leinert, S., Remeikis, V., Facchini, M. C., Prevot, A. S. H., Jennings, S. G., and O'Dowd, C. D.: Quantification of the carbonaceous matter origin in submicron marine aerosol particles by dual carbon isotope analysis, Atmos. Chem. Phys. Discuss., 11, 2749-2772, doi:10.5194/acpd11-2749-2011, 2011.

Charlson, R. J., Lovelock, J. E., Andreae, M. O., andWarren, S. G.: Oceanic phytoplankton, atmospheric sulphur, cloud albedo and climate, Nature, 326, 655-661, 1987.

Claeys, M. B., Wang, W., Vermeylen, R., Kourtchev, I., Chi, X., Farhat, Y.J., Surratt, D., GómezGonzález, Y., Sciare, J., and Maenhaut, W.: Chemical characterisation of marine aerosol at Amsterdam Island during the austral summer of 2006-2007, J. Aero. Sci., 41(1), 13-22, doi:10.1016/j.jaerosci.2009.08.003, 2009.

Clarke, A.: Aerosol light absorption by soot in remote environments, Aerosol Sci. Technol., 10,

\section{Wind speed dependent size-resolved parameterization}

B. Gantt et al.

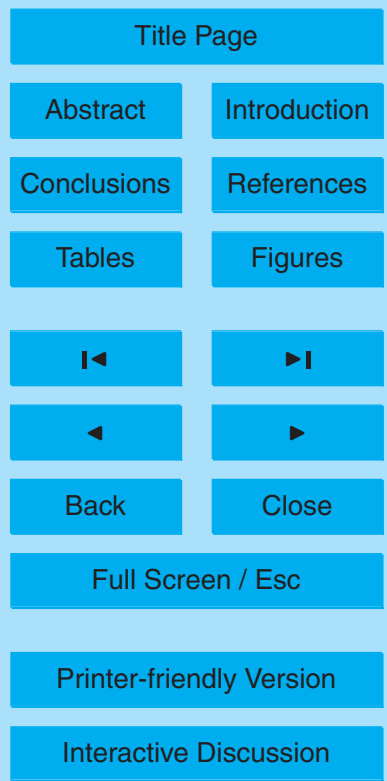


161-171, 1989.

Clarke, A. D., Owens, S. R., and Zhou, J.: An ultra?ne sea-salt flux from breaking waves: Implications for cloud condensation nuclei in the remote marine atmosphere, J. Geophys. Res., 111, D06202, doi:10.1029/2005JD006565, 2006.

5 Clement, A. C., Burgman R., and Norris J. R.: Observational and model evidence for positive low-level cloud feedback, Science, 325, 460-464, doi:10.1126/science.1171255, 2009.

Collins, W. D., Rasch, P. J., Boville, B. A., Hack, J. J., McCaa, J. R., Williamson, D. L., Briegleb, B. P., Bitz, C. M., Lin, S.-J., and Zhang, M.: The formulation and atmospheric simulation of the Community Atmosphere Model: CAM3, J. Climate, 19, 2144-2161, 2006.

10 de Leeuw, G., Neele, F. P., Hill, M., Smith, M. H., and Vignati, E.: Production of sea spray aerosol in the surf zone, J. Geophys. Res., 105(D24), 29397-29409, 2000.

Deane, G. B. and Stokes, M. D.: Scale dependence of bubble creation mechanisms in breaking waves, Nature, 418, 839-844, 2002.

Dysthe, K. B.: On surface renewal and sea slicks, Marine Surface Films: Chemical Characteristics, Influence on Air-Sea Interactions, and Remote Sensing, edited by: Gade, M., Huhnerfuss, H., and Korenowski, G. M., Springer, Berlin, 65-74, 2006.

Facchini, M. C., Rinaldi, M., Decesari, S., Carbone, C., Finessi, E., Mircea, M., Fuzzi, S., Ceburnis, D., Flanagan, R., Nilsson, E.D., de Leeuw, G., Martino, M., Woeltjen, J., and O'Dowd, C. D.: Primary submicron marine aerosol dominated by insoluble organic colloids 20 and aggregates, Geophys. Res. Lett., 35, L17814, doi:10.1029/2008GL034210, 2008.

Gantt, B., Meskhidze, N., and Kamykowski, D.: A new physically-based quantification of marine isoprene and primary organic aerosol emissions, Atmos. Chem. Phys., 9, 4915-4927, doi:10.5194/acp-9-4915-2009, 2009.

Gershey, R. M.: Characterization of seawater organic matter carried by bubble-generated aerosols, Limnol. Oceanogr., 28, 309-319, 1983a.

Gershey, R. M.: A bubble adsorption device for the isolation of surface-active organic matter in seawater, Limnol. Oceanogr., 28, 395-400, 1983b.

Gong, S. L.: A parameterization of sea-salt aerosol source function for sub- and super- micron particles, Global Biogeochem. Cy., 17(4), 1097, doi:1029/2003GB002079, 2003.

30 Hoffman, E. and Duce, R.: The organic carbon content of marine aerosols collected on Bermuda, J. Geophys. Res., 79(30), 4474-4477, 1974.

Hoffman, E. J. and Duce R.: Factors influencing the organic carbon content of marine aerosols: A laboratory study, J. Geophys. Res., 81(21), 3667-3670, 1976.

\section{ACPD}

$11,10525-10555,2011$

\section{Wind speed dependent size-resolved parameterization}

B. Gantt et al.

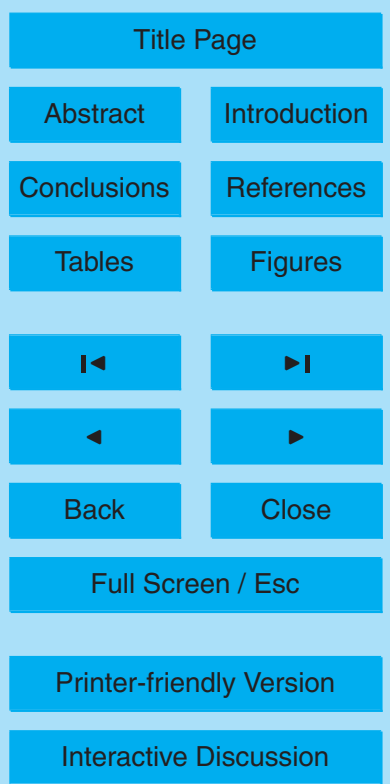


Hoose, C., Kristjánsson, J. E., Iversen, T., Kirkevåg, A., Seland, Ø., and Gettelman, A.: Constraining cloud droplet number concentration in GCMs suppresses the aerosol indirect effect, Geophys. Res. Lett., 36, L12807, doi:10.1029/2009GL038568, 2009.

Hsu, S. A., Meindl, E. A., and Gilhousen, D. B.: Determining the power-law wind-profile exponent under near-neutral stability conditions at sea, J. Appl. Meteor., 33, 757-765, 1994.

IPCC: The Physical Science Basis, in: Contribution of Working Group I of the Fourth Assessment Report of the Intergovernmental Panel on Climate Change, Cambridge University Press, Cambridge, UK, 2007.

Keene, W. C., Maring, H., Maben, J. R., Kieber, D. J., Pszenny, A. A. P., Dahl, E. E., Izaguirre, M. A., Davis, A. J., Long, M. S., Zhou, X. L., Smoydzin, L., and Sander, R.: Chemical and physical characteristics of nascent aerosols produced by bursting bubbles at a model air-sea interface, J. Geophys. Res., 112, D21202, doi:10.1029/2007JD008464, 2007.

Langmuir, I.: Surface motion of water induced by wind, Science, 87, 119-123, 1938.

Leibovich, S.: The form and dynamics of Langmuir circulations, Annual Review of Fluid Me15 chanics, 15, 391-427, 1983.

Liu, K. and Dickhut, R. M.: Effects of wind speed and particulate matter source on surface microlayer characteristics and enrichment of organic matter in southern Chesapeake Bay, J. Geophys. Res., 103(D9), 10571-10577, doi:10.1029/97JD03736, 1998.

Long, M. S., Keene, W. C., Kieber, D. J., Erickson, D. J., and Maring, H.: A sea-state based 20 source function for size- and composition-resolved marine aerosol production, Atmos. Chem. Phys., 11, 1203-1216, doi:10.5194/acp-11-1203-2011, 2011.

Luo, G. and Yu, F.: A numerical evaluation of global oceanic emissions of $\alpha$-pinene and isoprene, Atmos. Chem. Phys., 10, 2007-2015, doi:10.5194/acp-10-2007-2010, 2010.

Mannino, A., Russ, M. E, and Hooker, S. B.: Algorithm development and validation for satellitederived distributions of DOC and CDOM in the U.S. Middle Atlantic Bight, J. Geophys. Res., 113, C07051, doi:10.1029/2007JC004493, 2008.

Marmorino, G. O., Smith, G. B., Toporkov, J. V., Sletten, M. A., Perkovic, D. and Frasier, S. J. Evolution of ocean slicks under a rising wind, J. Geophys. Res. 113 (C4), C04030, doi:10.1029/2007JC004538, 2008.

30 Mårtensson, E. M., Nilsson, E. D., Cohen, L. H., and de Leeuw, G.: Laboratory simulations and parameterization of the primary marine aerosol production, J. Geophys. Res., 108(D9), 4297, doi:10.1029/2002JD002263, 2003.

Meskhidze, N. and Nenes, A.: Effects of ocean ecosystem on marine aerosol-cloud interaction,

\section{Wind speed dependent size-resolved parameterization}

B. Gantt et al.

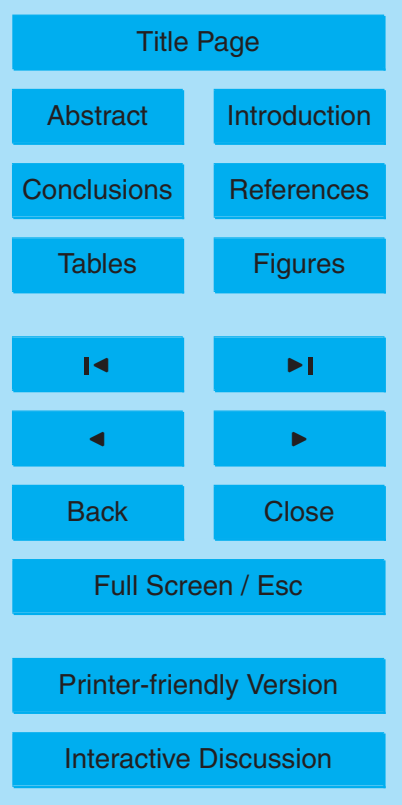


Adv. Meteorol., 2010, 239808, doi:10.1155/2010/239808, 2010.

Meskhidze, N. and Nenes, A.: Phytoplankton and cloudiness in the Southern Ocean, Science, 314, 1419-1423, doi:10.1126/science.1131779, 2006.

Middlebrook, A. M., Murphy, D. M., and Thomson, D. S.: Observation of organic material in indi5 vidual particles at Cape Grim during the First Aerosol Characterization Experiment (ACE1), J. Geophys. Res., 103, 16475-16483, 1998.

Miyazaki, Y., Kawamura, K., and Sawano, M.: Size distributions and chemical characterization of water-soluble organic aerosols over the Western North Pacific in summer, J. Geophys. Res., 115, D23210, doi:10.1029/2010JD014439, 2010.

10 Modini, R. L., Harris, B., and Ristovski, Z. D.: The organic fraction of bubble-generated, accumulation mode Sea Spray Aerosol (SSA), Atmos. Chem. Phys., 10, 2867-2877, doi:10.5194/acp-10-2867-2010, 2010.

Monahan, E. C. and O'Muircheartaigh, I. G.: Whitecaps and the passive remote sensing of the ocean surface, Int. J. Remote Sens., 7(5), 627-642, doi:10.1080/01431168608954716, 1986

O’Dowd, C. D., Facchini, M. C., Cavalli F., Ceburnis, D., Mircea, M., S. Decesari, Fuzzi, S., Yoon, Y. J. Putaud, J. P.: Biogenically driven organic contribution to marine aerosol, Nature, 431, 676-680, 2004.

O'Dowd, C. D. and de Leeuw, G.: Marine aerosol production: a review of the current knowledge, Phil. Trans. R. Soc. A, 365, 1753-1774, 2007.

O'Dowd, C. D., Langmann, B., Varghese, S., Scannell, C., Ceburnis, D., and Facchini, M. C.: A combined organic-inorganic sea-spray source function, Geophys. Res. Let., 35, L01801, doi:10.1029/2007GL030331, 2008.

Obernosterer, I., Catala, P., Lami, R., Caparros, J., Ras, J., Bricaud, A., Dupuy, C., van Wambeke, F., and Lebaron, P.: Biochemical characteristics and bacterial community structure of the sea surface microlayer in the South Pacific Ocean, Biogeosciences, 5, 693-705, doi:10.5194/bg-5-693-2008, 2008.

Oppo, C., Bellandi, S., Deglilnnocenti, N., Stortini, A. M., Loglio, G., Schiavuta, E., and Cini, R.: Surfactant components of marine organic matter as agents for biogeochemical fractionation and pollutant transport via marine aerosols, Mar. Chem., 63, 235-253, 1999.

O’Reilly, J. E., Maritorena, S., Mitchell, B. G., Siegel, D. A., Carder, K. L., Garver, S. A., Kahru, M. and McClain, C.: Ocean color chlorophyll algorithms for SeaWiFS, J. Geophys. Res., 103, 24937-24953, 1998.
ACPD

11, 10525-10555, 2011

\section{Wind speed dependent size-resolved parameterization}

B. Gantt et al.

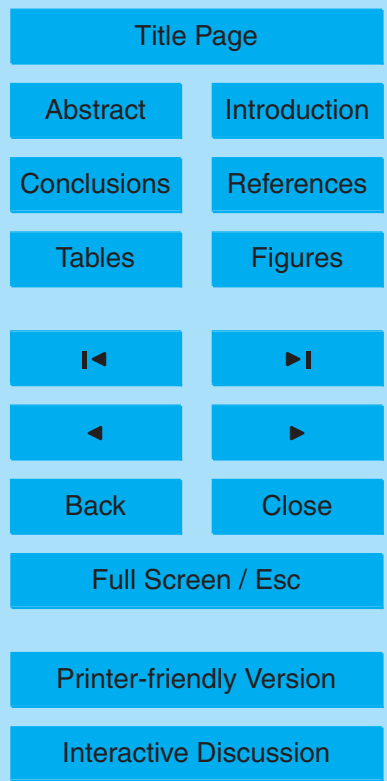


O’Reilly, J. E., Maritorena, S., Siegel, D., O’Brien, M. C., Toole, D., Mitchell, B. G., Kahru, M., Chavez, F. P., Strutton, P., Cota, G., Hooker, S. B., McClain, C. R., Carder, K. L., MullerKarger, F., Harding, L., Magnuson, A., Phinney, G. F., Moore, D., Aiken, J., Arrigo, K. R., Letelier, R. and Culver, M.: Ocean color chlorophyll a algorithms for SeaWiFS, OC2, and OC4: version 4, edited by: Hooker, S. B. and Firestone, E. R., SeaWiFS Postlaunch Technical Report Series, vol. 11 SeaWiFS postlaunch calibration and validation analyses: part 3, NASA Goddard Space Flight Center, Greenbelt, MD, 9-23, 2000.

Ovadnevaite, J., O'Dowd, C., Dall'Osto, M., Ceburnis, D., Worsnop, D. R., and Berresheim $\mathrm{H}$.: Detecting high contributions of primary organic matter to marine aerosol: A case study,

Petters, M. D. and Kreidenweis, S. M.: A single parameter representation of hygroscopic growth and cloud condensation nucleus activity, Atmos. Chem. Phys., 7, 1961-1971, doi:10.5194/acp-7-1961-2007, 2007.

Platnick, S. and Twomey S.: Determining the susceptibility of cloud albedo to changes in droplet concentration with the Advanced Very High-Resolution Radiometer, J. Appl. Meteorol., 33, 334-347, 1994.

Rinaldi, M., Facchini, M. C., Decesari, S., Carbone, C., Finessi, E., Mircea, M., Fuzzi, S., Ceburnis, D., Ehn, M., Kulmala, M., de Leeuw, G., and O'Dowd, C. D.: On the representativeness of coastal aerosol studies to open ocean studies: Mace Head - a case study, Atmos. Chem. Phys., 9, 9635-9646, doi:10.5194/acp-9-9635-2009, 2009.

Rinaldi, M., Decesari, S., Finessi, E., Giulianelli, L., Carbone, C., Fuzzi, S., O’Dowd, C. D., Ceburnis, D., and Facchini, M. C.: Primary and secondary organic marine aerosol and oceanic biological activity: Recent results and new perspectives for future studies, Adv. Meteorol., 2010, 310682, doi:10.1155/2010/310682, 2010.

Romano, J. C.: Sea-surface slick occurrence in the open sea (Mediterranean, Red Sea, Indian Ocean) in relation to wind speed, Deep-Sea Res., 43, 411-423, 1996.

Russell, L. M., Hawkins, L. N., Frossard, A. A., Quinn, P. K., and Bates, T. S.: Carbohydratelike composition submicron atmospheric particles and their production from ocean bubble bursting, P. Natl. Acad. Sci., 107(15), 6652-6657, doi:10.1073/pnas.0908905107, 2010.

30 Saltzman, E., Savoie, D., Zika, R., and Prospero, J.: Methane sulfonic acid in the marine atmosphere, J. Geophys. Res., 88(C15), 10897-10902, 1983.

Sciare, J., Favez O., Sarda-Estève R., Oikonomou K., Cachier H., and Kazan V.: Long-term observations of carbonaceous aerosols in the Austral Ocean atmosphere: Evidence of a bio-

\section{ACPD}

11, 10525-10555, 2011

\section{Wind speed dependent size-resolved parameterization}

B. Gantt et al.

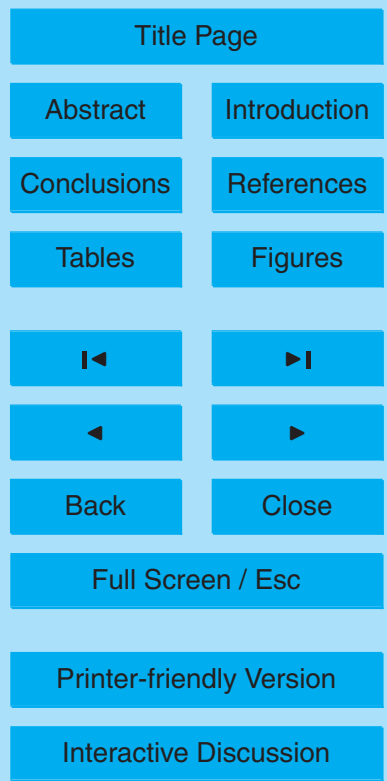


genic marine organic source, J. Geophys. Res., 114, D15302, doi:10.1029/2009JD011998, 2009.

Seinfeld, J. H. and Pandis, S. N.: Atmospheric Chemistry and Physics: From Air Pollution to Climate Change, 2 Edn., Wiley, Hoboken, NJ, USA, 444, 2006.

5 Sellegri, K., Villani, P., Picard, D., Dupuy, R., O'Dowd, C., and Laj, P.: Role of the volatile fraction of submicron marine aerosol on its hygroscopic properties, Atmos. Res., 90, 272-277, 2008.

Shaw, G. E.: Bio-controlled thermostasis involving the sulfur cycle, Clim. Change, 5, 297-303, 1983.

Siegel, D. A., Maritorena, S., Nelson, N. B., Hansell, D. A., and Lorenzi-Kayser, M.: Global distribution and dynamics of colored dissolved and detrital organic materials, J. Geophys. Res., 107(C12), 3228, doi:10.1029/2001JC000965, 2002.

Siegel, D. A., Maritorena, S., Nelson, N. B., Behrenfeld, M. J., and McClain, C. R.: Colored dissolved organic matter and its influence on the satellite-based characterization of the ocean biosphere, Geophys. Res. Lett., 32, L20605, doi:10.1029/2005GL024310, 2005.

15 Sorooshian, A., Padro, L. T., Nenes, A., Feingold, G., McComiskey, A., Hersey, S. P., Gates, H., Jonsson, H. H., Miller, S. D., Stephens, G. L., Flagan, R. C., Seinfeld, J. H.: On the link between ocean biota emissions, aerosol, and maritime clouds: airborne, ground, and satellite measurements off the coast of California, Glob. Biog. Cyc., 23, GB4007, doi:10.1029/2009GB003464, 2009.

Sorooshian, A. and Duong, H. T.: Ocean emission effects on aerosol-cloud interactions: Insights from two case studies, Adv. Meteorol., 2010, 301395, doi:10.1155/2010/301395, 2010.

Spracklen, D. V., Arnold, S. R., Sciare, J., Carslaw, K. S., and Pio, C.: Globally significant oceanic source of organic carbon aerosol, Geophys. Res. Lett., 35, L12811, doi:10.1029/2008GL033359, 2008.

Stramska, M.: Particulate organic carbon in the global ocean derived from SeaWiFS ocean color, Deep Sea Res. Pt. I, 56(9), 1459-1470, 2009.

Thomas, M. A., Suntharalingam, P., Pozzoli, L., Rast, S., Devasthale, A., Kloster, S., Feichter, J., and Lenton, T. M.: Quantification of DMS aerosol-cloud-climate interactions using the 30 ECHAM5-HAMMOZ model in a current climate scenario, Atmos. Chem. Phys., 10, 74257438, doi:10.5194/acp-10-7425-2010, 2010.

Turekian, V. C., Macko, S. A., and Keene, W. C.: Concentrations, isotopic compositions, and sources of size-resolved, particulate organic carbon and oxalate in near-surface marine air

\section{Wind speed dependent size-resolved parameterization}

B. Gantt et al.

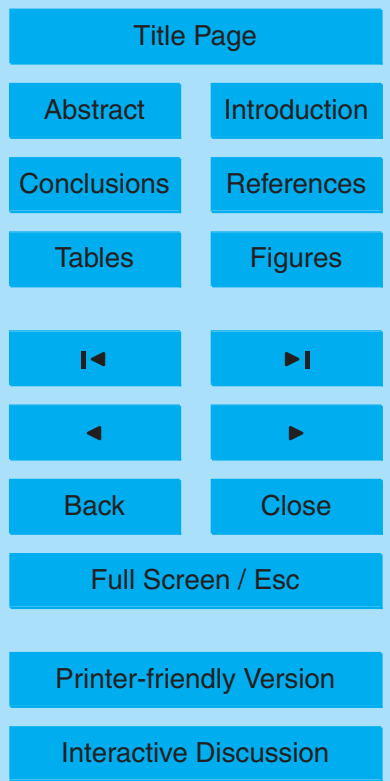


at Bermuda during spring, J. Geophys. Res., 108, 4157, doi:10.1029/2002JD002053, 2003.

Vignati, E., de Leeuw, G., and Berkowicz, R.: Modeling coastal aerosol transport and effects of surf-produced aerosols on processes in the marine atmospheric boundary layer, J. Geophys. Res., 106, 20225-20238, doi:10.1029/2000JD000025, 2001.

5 Vignati, E., Facchini, M. C., Rinaldi, M., Scannell, C., Ceburnis, D., Sciare, J., Kanakidou, M., Myriokefalitakis, S., Dentener, F., and O'Dowd, C. D.: Global scale emission and distribution of seaspray aerosol: sea-salt and organic enrichment, Atmos. Environ., 44, 670-677, 2010.

White, W. H.: Chemical markers for sea salt in IMPROVE aerosol data, Atmos. Environ., 42, 261-274, 2008.

10 Wurl, O., Wurl, E., Miller, L., Johnson, K., and Vagle, S.: Formation and distribution of sea-surface microlayers, Biogeosciences Discuss., 7, 5719-5755, doi:10.5194/bgd-7-57192010, 2010.

Yoon, Y. J., Ceburnis, D., Cavalli, F., Jourdan, O., Putaud, J. P., Facchini, M. C., Decesari, S., Fuzzi, S., Sellegri, K., Jennings, S. G., and O'Dowd, C. D.: Seasonal characteristics of the physicochemical properties of North Atlantic marine atmospheric aerosols, J. Geophys. Res., 112, D04206, doi:10.1029/2005JD007044, 2007.

Zhou, X. and Mopper, K.: Photochemical production of low molecular weight carbonyl compounds in seawater and surface microlayer and their air-sea exchange, Mar. Chem., 56, 201-214, 1997.

\section{ACPD}

$11,10525-10555,2011$

\section{Wind speed dependent size-resolved parameterization}

B. Gantt et al.

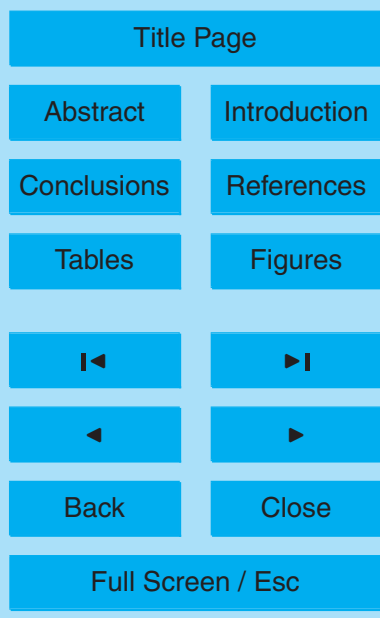

Printer-friendly Version

Interactive Discussion 


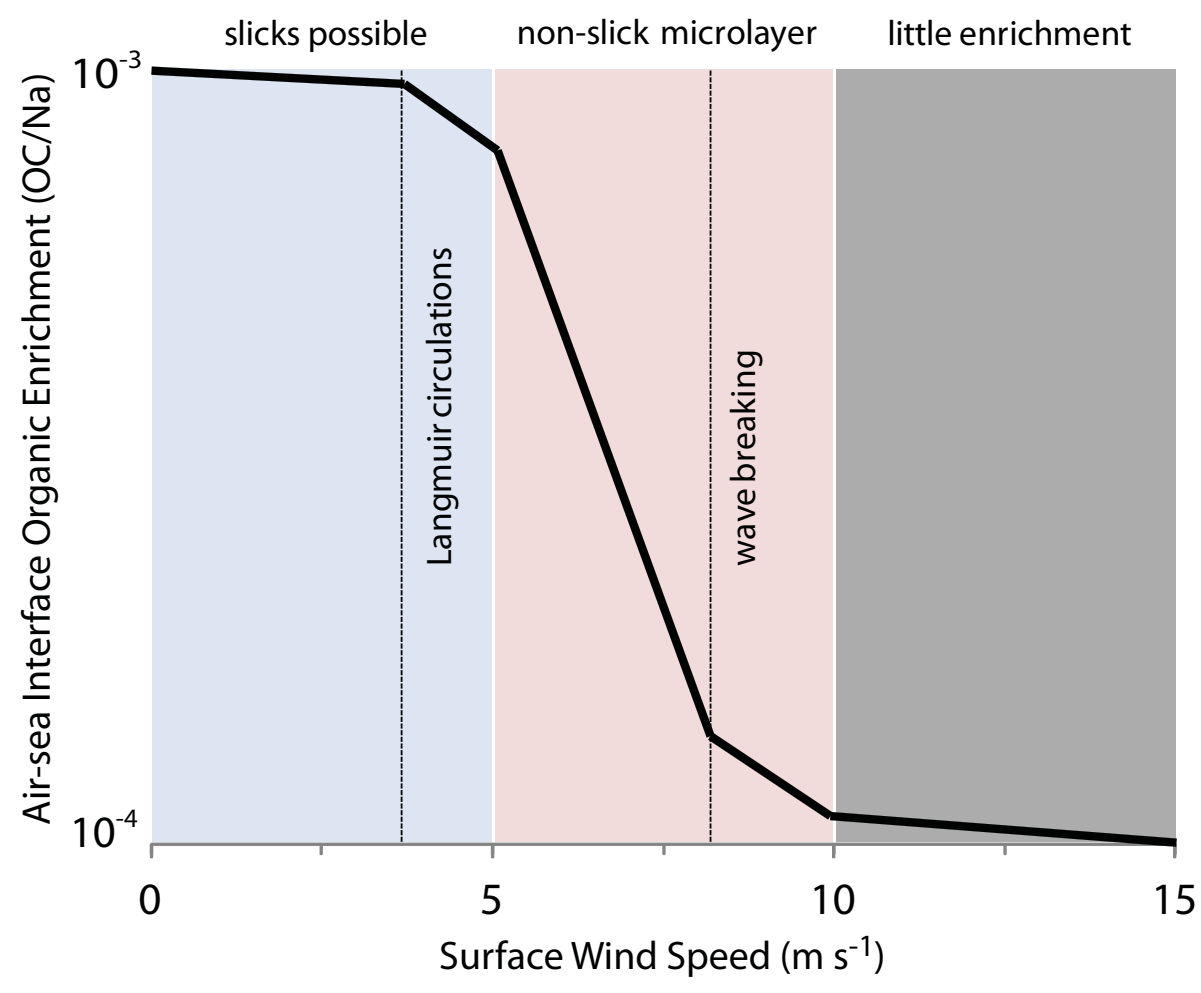

Fig. 1. Conceptual relationship between the organic enrichment of the air-sea interface and surface wind speed. Different colors depict potential regimes of the physical and chemical characteristics of the air-sea interface. These values represent global averages and may not be applicable for any given location.

\section{ACPD}

11, 10525-10555, 2011

\section{Wind speed dependent size-resolved parameterization}

B. Gantt et al.

\section{Title Page}

\section{Abstract}

Conclusions

\section{Tables}

14

4

Back

\section{Full Screen / Esc}

Printer-friendly Version 
a)

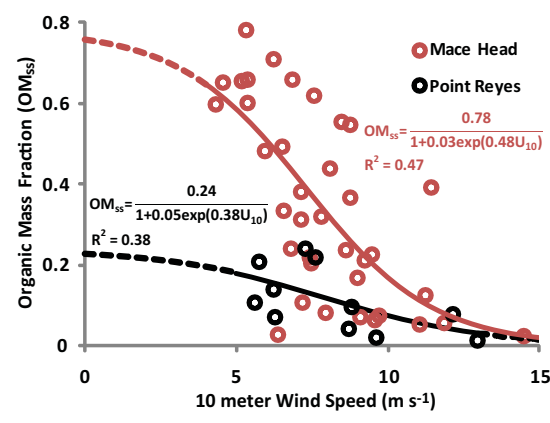

c)

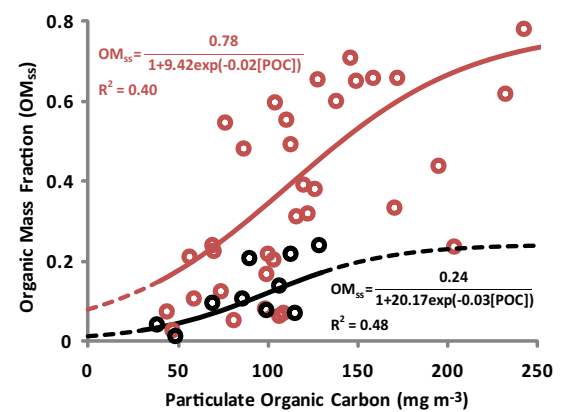

b)

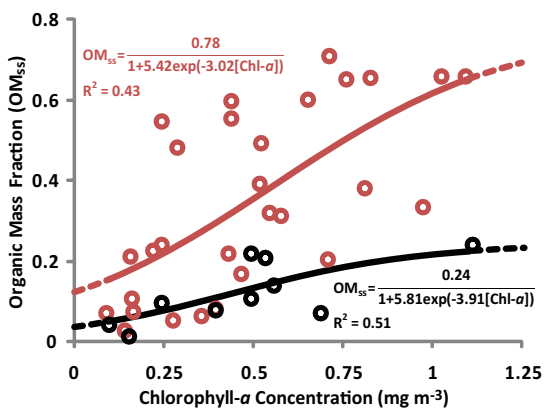

d)

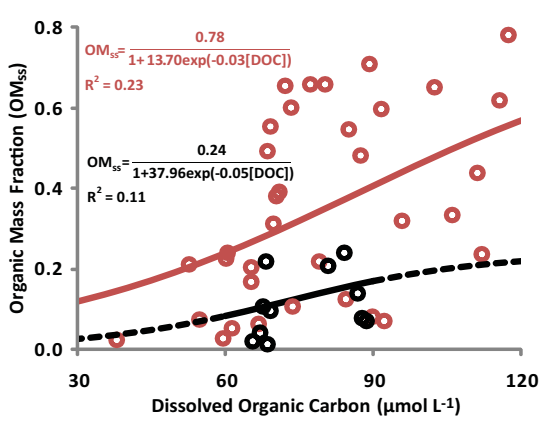

ACPD

$11,10525-10555,2011$

\section{Wind speed dependent size-resolved parameterization}

B. Gantt et al.

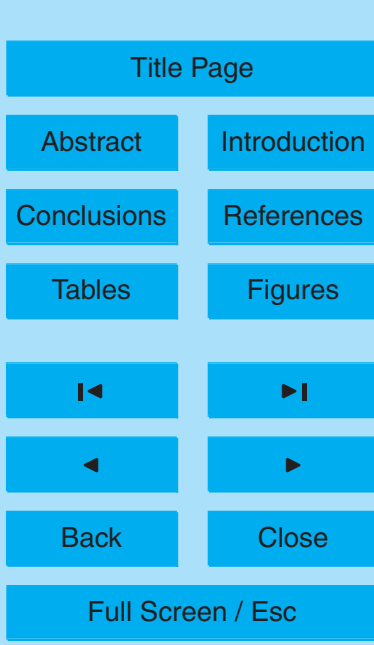

Printer-friendly Version

Interactive Discussion
Fig. 2. Organic mass fraction of sea spray as a function of (a) observed 10 meter wind speed $\left(U_{10}\right)$ and upwind averaged ocean concentrations of 8-day averaged (b) [Chl-a], (c) [POC], and (d) [DOC] for Mace Head and Point Reyes. In Fig. 2b, four outlier data points for Mace Head [Chl-a] $>1.25 \mathrm{mg} \mathrm{m}^{-3}$ have been excluded due to their occurrence during anomalously high chlorophyll-a concentrations in the region. The aerosol sizes measured at Mace Head and Point Reyes were $\mathrm{PM}_{1.5}$ and $\mathrm{PM}_{2.5}$, respectively, the solid lines show regression relationships for each station, and the dotted lines show an extrapolation of the regression relationship. 


\section{ACPD}

11, 10525-10555, 2011

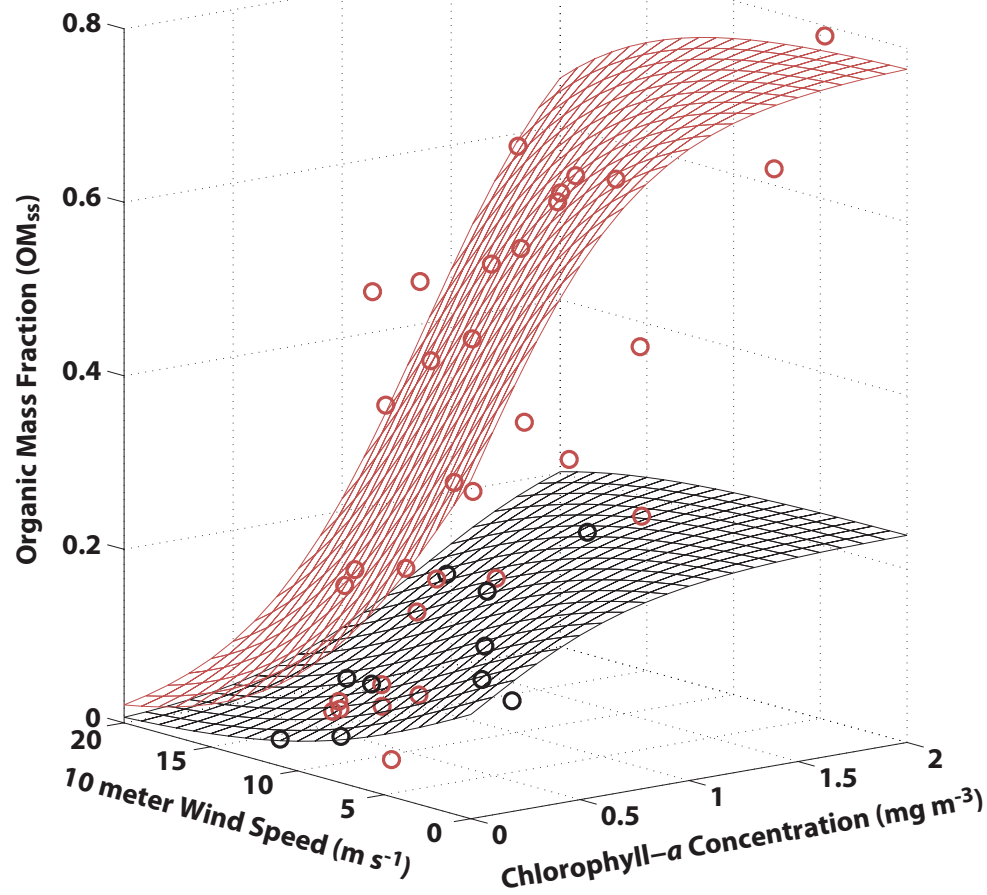

\section{Wind speed dependent size-resolved parameterization}

B. Gantt et al.

Title Page

Abstract Introduction

Conclusions

References

Tables

Figures

14

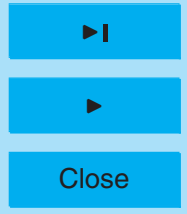

Back

Full Screen / Esc

Fig. 3. Organic mass fraction of sea spray as a function of both $10 \mathrm{~m}$ wind speed and [Chl-a] for Mace Head (red) and Point Reyes (black) with the surface regression based on Eq. (1) in the same color scheme for each site.

Printer-friendly Version

Interactive Discussion 


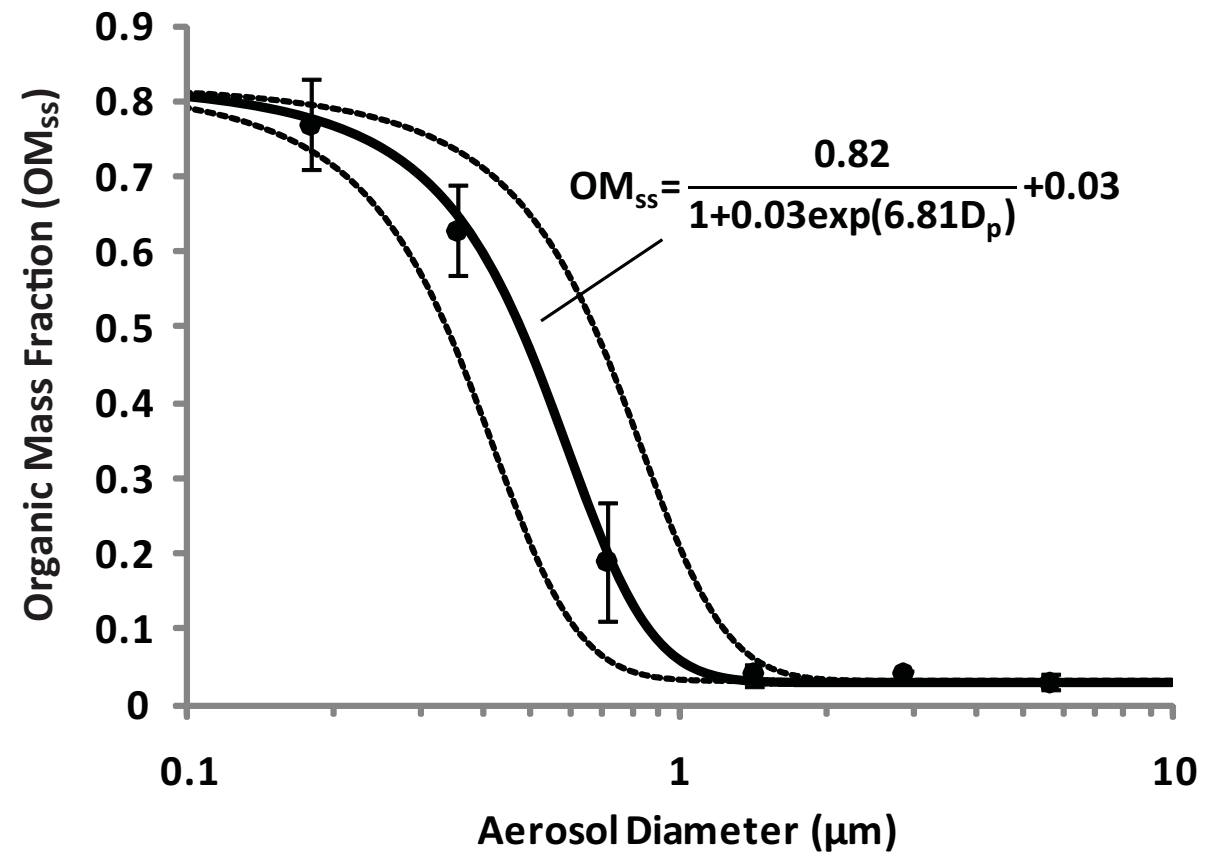

Fig. 4. Observed organic mass fraction of sea spray (solid circles) as a function of ambient aerosol aerodynamic diameter from Facchini et al. (2008). The solid curve shows a logistic fit to the geometric mean of the diameter range, with the dashed curves corresponding to the logistic fit of the high and low end of the measured aerodynamic size ranges. Vertical bars show one standard deviation from the mean as described in Facchini et al. (2008).

\section{ACPD}

$11,10525-10555,2011$

\section{Wind speed dependent size-resolved parameterization}

B. Gantt et al.

\section{Title Page}

\section{Abstract}

Conclusions

Tables

14

4

Back
Introduction

References

Figures

$\rightarrow$

$>$

Close

\section{Full Screen / Esc}

Printer-friendly Version

Interactive Discussion 


\section{ACPD}

11, 10525-10555, 2011

\section{Wind speed dependent size-resolved \\ parameterization}

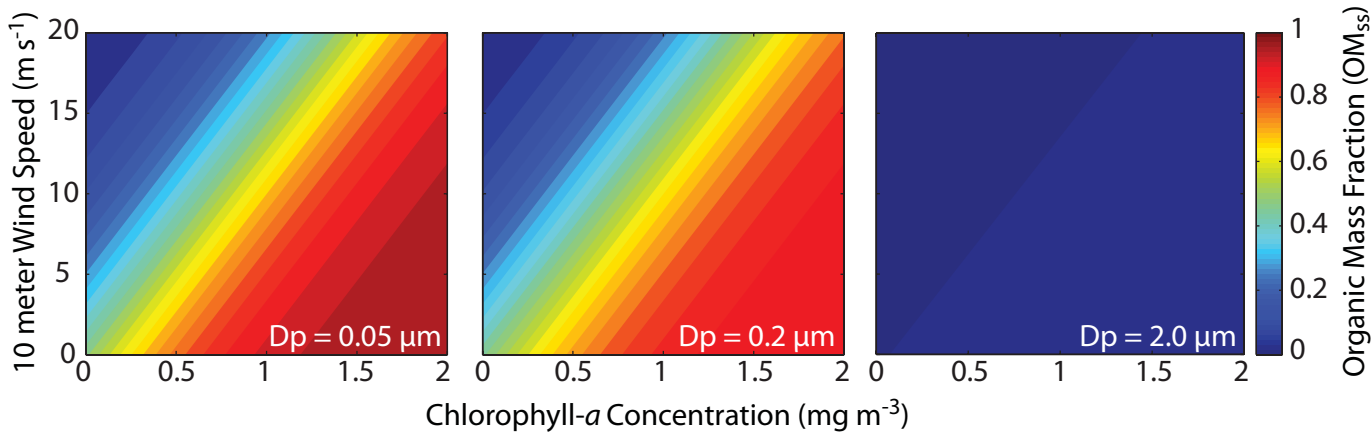

B. Gantt et al.

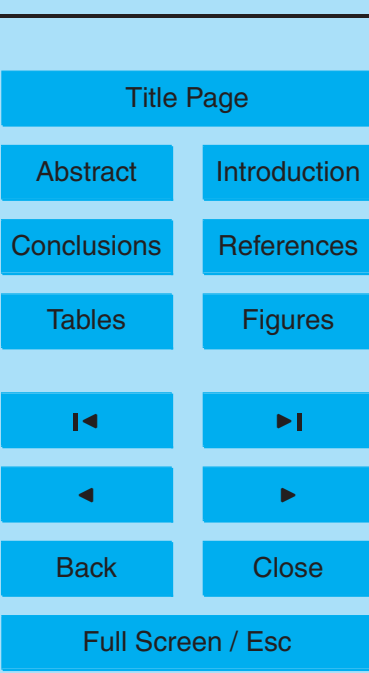

Printer-friendly Version

Fig. 5. Contour plots of the organic mass fraction of sea spray as a function of [Chl-a] and $10 \mathrm{~m}$ wind speed $\left(U_{10}\right)$ for sea spray aerosols with ambient aerodynamic diameters of (a) 0.05 , (b) 0.2 , and (c) $2 \mu \mathrm{m}$. (b)

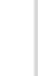




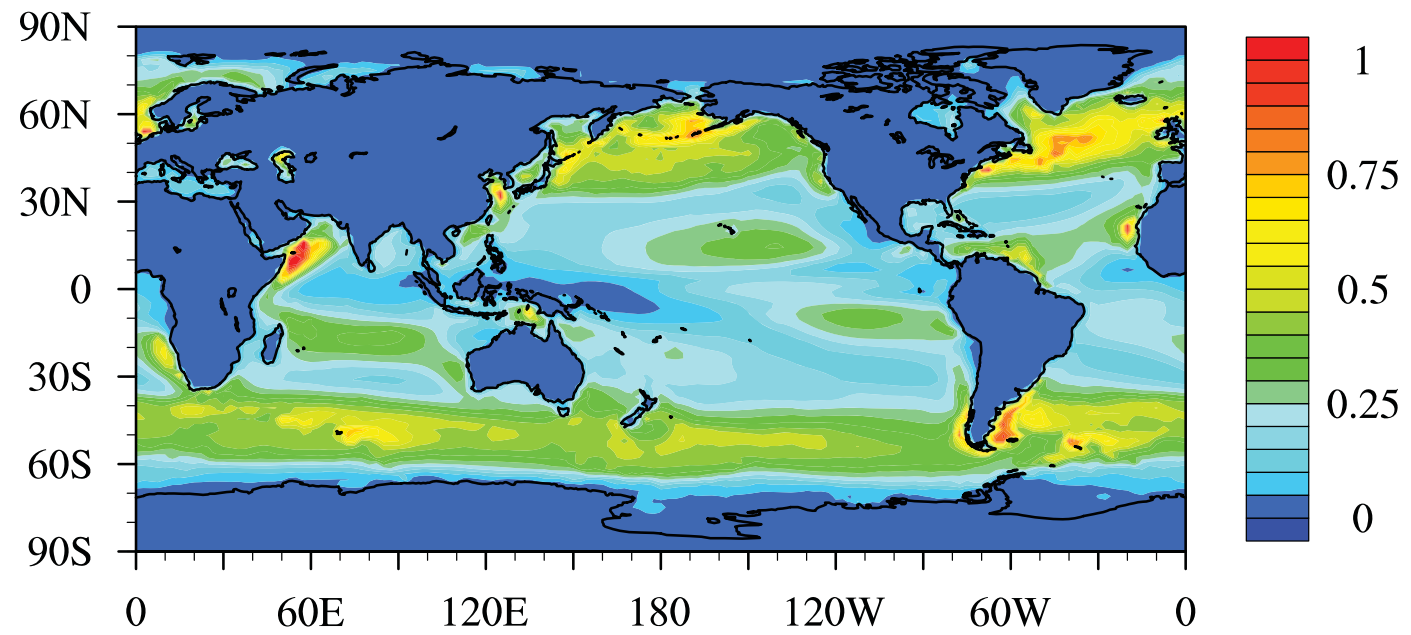

Fig. 6. Annual average submicron marine $P O A$ emission rate in units of $n g \mathrm{Cm}^{-2} \mathrm{~s}^{-1}$ using the Mårtensson et al. (2003) sea spray function, monthly average climatological [Chl-a] from SeaWiFS, and modeled $U_{10}$ when global submicron marine POA emissions are $2.8 \mathrm{Tg} \mathrm{Cyr}^{-1}$.

\section{ACPD}

$11,10525-10555,2011$

\section{Wind speed dependent size-resolved parameterization}

B. Gantt et al.

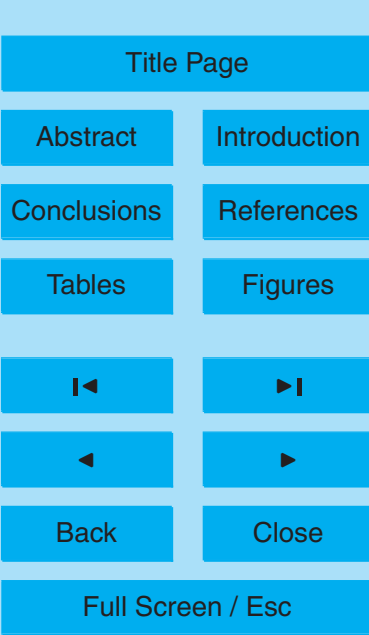

Printer-friendly Version

Interactive Discussion 